\title{
The changes they are a-timed: metabolism, endogenous clocks, and the timing of puberty
}

\section{Kristen P. Tolson ${ }^{\dagger}$ and Patrick E. Chappell *}

Department of Biomedical Sciences, College of Veterinary Medicine, Oregon State University, Corvallis, OR, USA

\section{Edited by:}

Carol F. Elias, University of Texas

Southwestern Medical Center, USA

\section{Reviewed by:}

Lance Kriegsfeld, University of

California, USA

Gloria E. Hoffman, Morgan State

University, USA

\section{*Correspondence:}

Patrick E. Chappell, Department of Biomedical Sciences, College of

Veterinary Medicine, Oregon State

University, Corvallis, OR 97331, USA

e-mail: patrick.chappell@

oregonstate.edu

\section{${ }^{\dagger}$ Present address:}

Kristen P. Tolson, Department of Reproductive Medicine, University of California San Diego, La Jolla, CA 92093, USA.
Childhood obesity has increased dramatically over the last several decades, particularly in industrialized countries, often accompanied by acceleration of pubertal progression and associated reproductive abnormalities (Biro et al., 2006; Rosenfield et al., 2009). The timing of pubertal initiation and progression in mammals is likely influenced by nutritional and metabolic state, leading to the hypothesis that deviations from normal metabolic rate, such as those seen in obesity, may contribute to observed alterations in the rate of pubertal progression. While several recent reviews have addressed the effects of metabolic disorders on reproductive function in general, this review will explore previous and current models of pubertal timing, outlining a potential role of endogenous timing mechanisms such as cellular circadian clocks in the initiation of puberty, and how these clocks might be altered by metabolic factors. Additionally, we will examine recently elucidated neuroendocrine regulators of pubertal progression such as kisspeptin, explore models detailing how the mammalian reproductive axis is silenced during the juvenile period and reactivated at appropriate developmental times, and emphasize how metabolic dysfunction such as childhood obesity may alter timing cues that advance or delay pubertal progression, resulting in diminished reproductive capacity.

Keywords: obesity, kisspeptin, circadian, puberty, GnRH
Normal development from childhood to adulthood involves the myriad changes accompanying puberty that most remember as awkward and unpleasant. In physiological terms, the process consists of activation of the hypothalamic-pituitary-gonadal (HPG) axis, which leads to the production of sex steroids and mature gametes as well as the ability to reproduce (Watanabe and Terasawa, 1989; Sisk et al., 2001; Harris and Levine, 2003). Normal reproductive function in mammals requires secretion of hypothalamic gonadotropin-releasing hormone $(\mathrm{GnRH})$ that stimulates release of pituitary gonadotropins needed for fertility in both males and females. GnRH pulses stimulate the secretion of luteinizing hormone ( $\mathrm{LH})$ and follicle-stimulating hormone (FSH), both of which act on the ovaries and testes to stimulate gonadal maturation, gametogenesis, and steroid hormone production. In adult females, preovulatory $\mathrm{GnRH}$ surges occur in response to increasing ovarian estrogen (E2) levels, which trigger LH surges responsible for ovulation (Levine and Ramirez, 1982; Moenter et al., 1992; Caraty et al., 1995; Herbison, 2008). The appearance of elevated LH surge secretion has been observed as a gradual process in female mammals, yet the signals responsible for this "awakening" of the reproductive axis are unclear. While the process of puberty has been well studied and work over the last century has contributed much to our understanding of associated physiological changes, molecular mechanisms have only started to be uncovered in the last decade and the trigger that initiates pubertal development is still highly debated.

\section{EVERYTHING IS BROKEN: ABNORMALITIES IN PUBERTAL PROGRESSION CORRELATE WITH METABOLIC DYSFUNCTION}

Although, or perhaps because, the transition through puberty is central to the survival of mammalian species, it can be perturbed by a number of factors. One major factor is nutrition, a viewpoint argued by some to have been conceptually acknowledged for millennia, as evidenced by obese ancient fertility statues such as the Venus of Willendorf. This ancient intuition of the link between nutrition and reproduction has been addressed in research in multiple animal models, including humans. It appears that, in order for normal pubertal development and reproduction to occur, a minimum positive energy balance must be maintained, particularly in females (Kennedy, 1969; Frisch and McArthur, 1974; Bergendahl et al., 1991; Kile et al., 1991; Aloi et al., 1997). Eating disorders, low body weight, and even weight loss can cause ovulatory dysfunction and infertility (Frisch and McArthur, 1974; Reid and Van Vugt, 1987). It is posited that, in times of famine, the reproductive axis becomes quiescent to ensure individual survival, shunting all efforts toward maintaining critical organs over maintenance of high energy cost functions such as sexual maturation, menstruation, pregnancy, and lactation. However, it appears that an excess of energy stores can also be detrimental: obesity in women is strongly associated with infertility and irregular cycles (Rittmaster et al., 1993; Bluher and Mantzoros, 2007). Rising obesity rates both in the United States as well as countries around the world (Flegal et al., 1998; Froguel and Boutin, 2001; Ogden et al., 2006)may be 
contributing to infertility rates and reproductive diseases such as polycystic ovarian syndrome (PCOS), a condition marked by cyst development in ovaries thought to be caused via overstimulation by LH (Rittmaster et al., 1993). Even more troubling, the rising rates of childhood obesity may be altering both the rate of pubertal progression as well as later reproductive function (Freedman et al., 2003; Biro et al., 2006, 2010; Ogden et al., 2006; Walvoord, 2010). The decline in reproductive health in humans, farm animals, and wildlife, as well as the rising incidence of cancers of the reproductive system, has led to an increased public desire for answers as to why these changes are occurring and how to prevent them.

The age of menarche, defined as occurrence of the first menstrual period in girls, has decreased over the last 200 years (Wyshak and Frisch, 1982), but whether or not this trend has continued or even accelerated over the last couple of decades is both debated (Walvoord, 2010) and a source of concern (Euling et al., 2008). While difficulties are encountered making direct comparisons between studies due to differences in study design and methods, it currently appears that childhood obesity is one of the main factors underlying observed increases in rates of early puberty onset and menarche (Biro et al., 2001; Kaplowitz et al., 2001; Davison et al., 2003; Freedman et al., 2003; Lee et al., 2007; Ong et al., 2009; Rosenfield et al., 2009). As the rates of childhood obesity continue to rise globally, it is possible that the cases of early puberty in girls will continue to rise as well. Some well-controlled studies from Denmark recently reported that puberty in girls today begins a full year earlier compared to girls 15 years ago. However, this change in the timing of the onset of puberty was not accompanied by changes in age at menarche (Aksglaede et al., 2009; Sorensen et al., 2010), suggesting that the multiple processes comprising puberty can be disassociated. A more thorough understanding of the developmental signals required for initiating the process of puberty is therefore crucial to determine how metabolic disorders may affect pubertal timing. This understanding starts with analyzing the observed changes in the patterns of reproductive hormonal secretion observed during the pubertal transition.

\section{FEEL A CHANGE COMIN" ON: REPRODUCTIVE HORMONAL RHYTHMS IN PUBERTY}

Reproductive hormone secretion in mammals over developmental time displays a unique pattern: near adult levels are in circulation at birth and in infancy, followed by dramatically decreasing concentrations for the span of several weeks, months, or years during juvenile development in a species-dependent manner, finally followed by a gradual re-awakening of the reproductive axis culminating in puberty. The origins of the intervening "juvenile pause" and what cues lead to the resumption of reproductive axis function remain as yet unclear. Two main models of pubertal progression have been proposed: one describes a "brake" mechanism that must be released for puberty to begin, while the other consists of an "accelerator" that must be fueled to start puberty (Sirinathsinghji et al., 1985; Mayer et al., 2010). The concept of a "brake" implicates elevated activity of inhibitory mechanisms underlying the juvenile pause, with a timed disinhibition responsible for initiating puberty. While some earlier studies hinted at this possibility by demonstrating an increase in hypothalamic GABAergic tone during juvenile development (Clarkson and Herbison, 2006a), and that serotonin and GABA administered centrally can be stimulatory to $\mathrm{GnRH} / \mathrm{LH}$ secretion in pre-pubertal female rats, while becoming inhibitory to $\mathrm{GnRH} / \mathrm{LH}$ release in adults (Moguilevsky and Wuttke, 2001), this may be difficult to reconcile with recent findings that GABA actually depolarizes a subset of GnRH neurons, thus increasing secretion (Sim et al., 2001; Moenter and DeFazio, 2005). Still other studies support the "accelerator" hypothesis, demonstrating that catecholamines and NMDA in the hypothalamus begin to rise nearing puberty, pharmacological blockade of NMDA receptor signaling can prevent E2-primed LH surges in peri-pubertal females, and central NMDA treatment can accelerate pubertal timing (Urbanski and Ojeda, 1987, 1990; Gore et al., 1996). Still other studies have suggested a role for glial factors such as prostaglandins that may prime neuroendocrine neurons to exhibit altered sensitivity to both neurotransmitters and steroid hormones at developmentally appropriate times (Ma and Ojeda, 1997; Ojeda and Ma, 1999; Ojeda et al., 2000). PGE 2 stimulates $\mathrm{GnRH}$-activating norepinephrine (NE) release within the mediobasal hypothalamus, an effect which is potentiated by E2, suggesting that astrocytes may participate in sensitizing the neuroendocrine hypothalamus to the positive feedback effects of E2 (Ojeda et al., 1986). Hypothalamic glia may also contribute to pubertal development by production of transforming growth factor $\alpha$ (TGF $\alpha)$ and its receptors, effects which can also be modulated by E2 exposure (Rage et al., 1997; Ojeda and Ma, 1999; Prevot et al., 2005). Few of these models, however, provide insight as to what factors may signal to putative mechanisms at the appropriate developmental times. Since proper pubertal progression appears to require a threshold basal metabolic state, we will explore below recent literature probing how peri-pubertal metabolic cues may signal the hypothalamus to initiate a cascade of cellular events leading to puberty.

In addition to the above long-term changes in baseline peptide, glycoprotein, and steroid hormone release, a striking feature of secretion in pre-pubertal rodents (Kimura et al., 1981), primates (Plant, 1985), and humans (Wu et al., 1991) is an approximate 24h rhythmicity of several reproductive hormones, rhythms that can begin quite early ( $6-8$ years of age) and persist through puberty, to diminish in the adult (Oerter et al., 1990; Dunkel et al., 1992; Apter et al., 1993; Albertsson-Wikland et al., 1997; Ankarberg-Lindgren and Norjavaara, 2004). In particular, pulses of LH increase initially only at night in humans, until during later puberty when daytime LH secretion increases to match the elevated nighttime release already established (Porcu et al., 1997). Interestingly, in some post-pubertal girls with abnormally high testosterone or obesity, these rhythms appear to persist into adulthood and are often associated with decreased reproductive capacity (Porcu et al., 1997), which suggests that while these rhythms may play a role in pubertal progression, they may be unnecessary and possibly detrimental to adult reproductive patency. Other studies indicate that normal daily rhythms of LH secretion may be altered in patients with peri-pubertal obesity or PCOS, who display relative increases in daytime release in comparison to controls (McCartney, 2010). Diurnal rhythms of sex steroids, particularly E2, have also been observed during puberty in girls, but mostly these release patterns are evident only following (in response to) rhythmic LH secretion, and peak in the morning after the nocturnal rise in 
LH (Norjavaara et al., 1996), thus suggesting that the neuroendocrine components (i.e., the hypothalamus and pituitary) of this axis are primarily responsible for initiating pubertal progression. Supporting this, studies in primates have demonstrated that pre-pubertal increases in rhythms of GnRH and LH secretion can occur even in gonadectomized (GDX) animals (Chongthammakun and Terasawa, 1993; Chongthammakun et al., 1993). Further, many other daily hormonal rhythms, including those indicative of metabolic condition, such as leptin, growth hormone $(\mathrm{GH})$, and insulin-like growth factor-1 (IGF-I), occur at the same developmental time in relation to puberty whether animals have been GDX or not (Suter et al., 2000), suggesting that the presence of circulating sex steroids in primates may not be required to generate these rhythms. While some hormonal rhythms are associated with sleep-wake cycles, evidence is accumulating that most patterns may be generated by endogenous circadian clocks.

\section{ALL ALONG THE CLOCKTOWER: ENDOGENOUS CLOCKS WITHIN THE REPRODUCTIVE AXIS}

Since this review explores potential pubertal timing mechanisms, it is worthwhile to consider how both central and peripheral molecular timing devices may contribute to pubertal progression, especially considering the rhythmic patterns of reproductive hormone release in early puberty. The model of molecular timing most recently elucidated is the intracellular circadian clock, consisting of transcriptional-translational feedback loops within each cellular oscillator, in which a heterodimer of the transcription factors CLOCK and BMAL1 bind to the promoters of Period (Per1-3) and Cryptochrome (Cry1/2) genes and drive production of the PER and CRY proteins, which return to the nucleus following phosphorylation in the cytoplasm to inhibit their own transcription (Reppert and Weaver, 2002; Ko and Takahashi, 2006). Each cellular oscillator is then synchronized within a tissue by currently uncharacterized factors, and expression patterns within this tissue-level oscillator can be adjusted to changes in the ambient light environment via signals from the hypothalamic suprachiasmatic nuclei (SCN), which receives direct photic input from the retina (Yoo et al., 2004). Since the relatively recent elucidation of many of the genes involved in the core clock mechanism, several genetic models of molecular circadian clock disruption have been generated with varying results on reproduction and puberty (Boden and Kennaway, 2006). Mice harboring a somatic knockout of the core clock gene Bmall exhibit significantly delayed puberty in addition to a loss of other activity and hormone secretion rhythms (Boden and Kennaway, 2004, 2005), while mutation of its heterodimeric partner Clock, which also disrupts free-running locomotor rhythms, appears to have little effect on pubertal progression, although adult females are subfertile (Chappell et al., 2003; Kennaway et al., 2004; Miller et al., 2004). Interestingly, lesions of the SCN disrupt adult estrous cyclicity, but appear to have no effect on rates of pubertal progression, at least in rats (Mosko and Moore, 1979). It is unknown, however, if pre-pubertal rhythms of hormone secretion persist in SCN-ablated animals. If so, this could indicate that the SCN may not be required for these reproductive rhythms, instead implicating autonomous cell-specific oscillators within the reproductive axis itself, evidence for which has been growing.
Awareness of the development and participation of cellular circadian oscillators is of particular interest to studies of pubertal initiation, given the rhythmic nature of reproductive hormone secretion prior to and during puberty. These molecular oscillators appear to function in multiple reproductive axis components, including GnRH neurons (Chappell et al., 2003; Gillespie et al., 2003; Olcese et al., 2003; Hickok and Tischkau, 2009), anterior pituitary cells including gonadotropes (Yoo et al., 2004; Resuehr et al., 2007), adrenal cortical cells (Fahrenkrug et al., 2008; Son et al., 2008), and within steroidogenic cells in the gonads (Fahrenkrug et al., 2006; Karman and Tischkau, 2006; He et al., 2007; Nakao et al., 2007; Alvarez et al., 2008; Bebas et al., 2008; Sellix and Menaker, 2010). This suggests that development of all or some of these tissue-specific oscillators may contribute to the observed reproductive hormonal rhythms. In developing rodents, changes in hormone secretory rhythms are often mirrored by alterations in locomotor activity patterns, in which both males and females elicit bimodal bouts of activity pre-pubertally that consolidate into a single period of activity in the dark phase shortly after puberty, as measured by preputial separation in males and vaginal opening (VO) in females (Hagenauer et al., 2011). In both sexes, the later bout of activity phase advances over several days/weeks to eventually merge with the activity peak observed at lights off. Interestingly, this activity consolidation appears to be mediated by the actions of gonadal steroids, since GDX males and females exhibited bimodal activity patterns into adulthood. Additionally, testosterone administration to GDX males can reverse this pattern (Daan et al., 1975; Morin and Cummings, 1981). These patterns, at least in rodents, are circadian in nature and are not merely sleepassociated, as the above effects persist in peri-pubertal animals raised in constant darkness (Hagenauer et al., 2011). What portion of trigger for pubertal initiation, then, is mediated by these endogenous timing mechanisms is unclear; however, exogenous signals that can entrain these cellular oscillators can exert robust effects on the timing of puberty.

\section{HOUSE OF THE RISING SUN: PHOTOPERIODIC CUES AND PUBERTAL PROGRESSION}

Over the last several decades, it has become clear that photic cues, indicating not only the present point within the light/dark phase, but also communicating day length, play a large part in determining rhythms of hormone synthesis and secretion, and are clearly involved in timing sexual maturity in both opportunistic and seasonal breeders. Light stimulates specific melanopsin-expressing ganglia within the retina that signal to the SCN via a monosynaptic pathway (Ebling, 2010). SCN entrainment, in turn, uses sympathetic connections to the pineal gland, which then inhibits or stimulates melatonin production in the light or dark phase, respectively (Ebling, 2010). Melatonin production therefore acts also to reflect changes in day length, the evaluation of which is crucial to short-lived seasonal breeders. Recent evidence indicates that while many brain regions and peripheral tissues express melatonin receptors MT1 and MT2, the pars tuberalis of the pituitary is an important melatonin-binding region, acting as an interval timer to communicate the progression of shorter or longer day lengths to the reproductive axis and other physiological axes (Lincoln et al., 2002; Hazlerigg and Wagner, 2006). 
If the possibility exists, then, that circadian clocks may be involved in the development of hormonal rhythms within the reproductive axis, is there evidence that pubertal changes become programmed during or after the development of circadian physiology? Recent studies in rats indicate that although molecular rhythms in the SCN and periphery develop quite early, during fetal development, and are "ticking" even in neuronal precursor cells (Kowalska et al., 2010), the ability to entrain and couple oscillators to behaviors develops later, temporally associated with the critical window of organizational steroid exposure. Orbital enucleation of juvenile rats prior to postnatal day 11 results in diurnal (in contrast to nocturnal) activity in these animals, whereas the same procedure performed later has no effect on the consolidation of activity in the dark phase (Gall et al., 2008). Unfortunately, it was not determined whether early enucleation permanently affects or shifts the timing of pubertal progression.

Evidence also exists that circadian patterns of neuronal activity are associated with normal reproductive function, and additionally that appropriate phase relationships among neurotransmitter release may be required. In a recent study, it was found that pharmacologically administered serotonin and dopamine precursors were able to increase testicular development in mice when given in a phase relationship $12 \mathrm{~h}$ apart, while a more "dissonant" phase relationship of $8 \mathrm{~h}$ between treatments impaired testicular growth, testosterone production, and spermatogenesis (Sethi and Chaturvedi, 2011). These data suggest that even in mice, which are continuous and not seasonal breeders, a mechanism of an internal coincidence timer exists, in which phase relationships of neuroendocrine activation typically induced by changes in photoperiod can profoundly affect the development of the reproductive axis. Seasonal breeders typically use this "internal coincidence model" to time pubertal progression to coincide with an optimal photoperiod for reproduction. In these species, including sheep and Siberian hamsters, photoperiodic control exerts considerable influence on pubertal progression (Foster et al., 1985). In fact, in seasonal breeders, achievement of a particular body size and nutritional state is clearly not the only component required for pubertal progression. Early studies revealed that lambs born under decreasing light conditions (i.e., in the autumn) reach pubertal size in the spring, yet delay puberty until the subsequent autumn, which suggests that photoperiodic cues in this species can override metabolic signals for progression (Foster and Ryan, 1979; Foster et al., 1986). Intriguingly, this observed delay is not a result of a decreased ability to secrete $\mathrm{GnRH} / \mathrm{LH}$, as gonadectomy of autumn-born lambs increases LH dramatically, demonstrating an intact negative feedback response to steroids (Foster and Ryan, 1981). Instead, this mechanism appears to represent an inability of the GnRH secretory system to respond to E2 with positive feedback-style surges, as E2 implantation in these animals continues to exert only negative feedback, profoundly inhibiting LH release (Foster et al., 1985). In contrast, lambs born in the spring ovulate normally in the fall, even as day length is decreasing; however experimental exposure to artificially shortened days can delay ovulation for up to a year. Under artificial short-day photoperiods, however, 1 week of long-day light exposure is sufficient to initiate ovulation following a return to a short-day photoperiod (Foster and Ryan, 1981), demonstrating a high sensitivity to changes in day length even during this refractory period. A similar regulatory mechanism exists in Siberian hamster females, who can either advance or delay puberty depending on when they are born in relation to the summer solstice (Butler et al., 2007). Females born into an environment of decreasing day lengths will delay puberty until the following spring, while females born a few weeks earlier will in many instances advance puberty, illustrating the importance of photoperiodic control over pubertal initiation (Butler et al., 2007). These findings also demonstrate that puberty can begin over a broad range of body mass, as pups born after the solstice attain the same weight as their counterparts when they begin pubertal progression. The above study used simulated natural photoperiods to mimic natural progression of day lengths; however, in a static photoperiodic setting, only Siberian hamster females exposed to light/dark conditions attain puberty, exhibiting commensurate increases in body weight, as well as increases in hypothalamic leptin receptor, and pro-opiomelanocortin (POMC) expression (Adam et al., 2000). Taken together, these findings indicate that even once a target body weight has been reached, photoperiodic cues exert profound effects on the timing of pubertal initiation.

There exist further variations in the timing of puberty relative to circadian activity, as illustrated by the Octodon degus, a diurnal Chilean rodent that exhibits a much longer estrous cycle than rats, mice, and hamsters. These animals begin to exhibit a sexual dimorphism in free-running locomotor activity long after puberty has concluded, a phenomenon dependent on gonadal steroids (Lee et al., 2004). In this model, circadian period is influenced after puberty, most likely by the development of sex steroid receptors in the SCN. Gonadectomy following puberty results in no period differences from what would be expected in intact animals, however, suggesting that while the actions of gonadal steroids are considered "organizational," effects exerted by this exposure are delayed until well past puberty. Much of the communication of photoperiodic encoding to the reproductive axis is performed by increased melatonin release from the pineal gland during the dark phase, as is evidenced by the absence of pubertal progression in pinealectomized ewes (Yellon and Foster, 1986). In conflict with this, however, are data showing that short-day patterns of melatonin secretion alone are not sufficient to initiate puberty (Yellon and Foster, 1986). While cues communicating metabolic status in seasonal breeders are insufficient to induce puberty, nutritional status may still play a role in allowing the development of the transition from a negativeto a positive feedback response to E2 in females. In peri-pubertal ewes, undernutrition potentiated the negative feedback effects of E2 on LH secretion, while increasing nutrition resulted in the ability of E2 to accelerate LH pulse frequency and amplitude (Foster et al., 1985). The interaction of the developing circadian system, as well as changes in neuroendocrine gene expression, occur against a backdrop of alterations in exposure to steroid hormone levels beginning in utero, adding a further layer of complexity.

\section{MAMA, YOU BEEN ON MY MIND: ORGANIZATIONAL EFFECTS OF PRE-PUBERTAL STEROID EXPOSURE ON PUBERTAL TIMING}

There is a considerable amount of evidence pointing to the role of perinatal steroid hormone exposure in programming sexual differentiation and later pubertal development, although it remains 
unclear what role this exposure may play in setting the timing of pubertal progression. In particular, several studies demonstrate that perinatal exposure of females to testosterone can masculinize portions of reproductive axis function, and is correlated with early puberty, altered linear growth rate, and the development of PCOS (Ibanez et al., 1996, 1998b, 2006; McCartney et al., 2007). This is of particular significance, given that elevated testosterone has been found to correlate with the insulin resistance that accompanies childhood obesity in pre-pubertal girls (Ibanez et al., 2009). Testosterone, likely of adrenal origin, may thus exacerbate problems associated with metabolic dysfunction, and may impact the reproductive axis by accelerating puberty. This rise in testosterone may be dissociated from gonadotropin stimulation, however, since earlier studies in juveniles suggest that testosterone production in males is not responsive to LH stimulation. Indeed, in hypophysectomized juvenile male rats, $\mathrm{LH}$ administration has little to no effect on testosterone production, in contrast to the marked response observed in adults (Odell and Swerdloff, 1976).

In female juvenile rats, circulating E2 remains relatively high until weaning, after which levels severely diminish until gradual diurnal increases in LH stimulate ovulation (Ojeda et al., 1976), and yet it remains unclear precisely when pituitary responsiveness to either GnRH or sex steroids becomes fully developed. In juvenile rats, gonadotropes in the anterior pituitary appear to respond to GnRH administration by preferentially increasing $\mathrm{FSH}$ over LH as early as 15 days of age (Debeljuk et al., 1972). Interestingly, this preference for FSH secretion appears to be dependent on E2, as it is reversed by ovariectomy (Ojeda et al., 1976), suggesting that ovarian E2 even in juveniles may play a role in determining gonadotropin levels. Even though the gonads may be unresponsive to gonadotropins in early juvenile development, the hypothalamic-pituitary components of the reproductive axis appear to still be responsive to the negative feedback effects of steroids: some early studies suggest that even under the conditions of low circulating sex steroids found in pre-pubertal animals, negative feedback responses to steroids are functional. Testosterone was found to be equally effective at decreasing basal LH levels in GDX male rats at 10,21, or 70 days of age (Odell et al., 1974), and E2 was found to effectively suppress gonadotropin levels in juvenile female rats, but unable to elicit preovulatory LH surges until later development (Andrews et al., 1981). These results are inconsistent with the previously posited "gonadostat" theory of puberty, in which sensitivity to the negative feedback effects of steroids is altered throughout development. This hypothesis states that the juvenile pause results from an increased sensitivity to sex steroids during this developmental window (applying the "brake"), and also that free steroids are relatively plentiful due to a drop in serum hormone binding globulin (SHBG) observed during this period. However, studies in primates have found a robust sexual dimorphism in $\mathrm{GnRH} / \mathrm{LH}$ responsiveness to pre-pubertal gonadectomy, resulting in dramatic increases in secretion only in females (Plant, 1985, 1986), suggesting that the development of classical feedback responses of the brain to sex steroids prior to puberty is not universal among species or between sexes.

The most intriguing and perplexing results regarding the timing of pubertal progression are found in exploration of the origins of positive feedback in females, particularly in rodents. Even though
$\mathrm{VO}$ in rats does not occur until $\sim$ day 35, a bolus of E2 can elicit an LH surge as early as 21 days, and progesterone injection in E2-primed juvenile females can elicit surges as early as 14 days of age (Puig-Duran and MacKinnon, 1978). These data align with the recent work in transgenic mouse females in which estrogen receptor alpha $(\mathrm{ER} \alpha)$ was selectively deleted from Kiss1expressing neurons (discussed in detail below), which display VO at 10-15 days (Mayer et al., 2010). If the capacity to produce preovulatory LH surges in response to ovarian steroids is present at this stage of development, then why is there the observed delay? Additionally, studies in primates suggest that the inhibition of $\mathrm{GnRH} / \mathrm{LH}$ secretion during the juvenile pause and the initiation of puberty are regulated by timed changes in the CNS and triggered not by gonadal steroids but by other peripheral factors indicating that a threshold metabolic state has been achieved. If this were the case, why then would an ER $\alpha$-dependent phenomenon be required for the juvenile pause? Perhaps pre-weaning levels of circulating E2 are required to keep the reproductive axis at bay until central inhibitory mechanisms are fully developed, or until the development of hypothalamic circuitry capable of reacting to E2 with both negative and positive feedback responses. The most compelling hypothalamic neuropeptidergic candidate modulating pubertal initiation, kisspeptin, is discussed in detail below. Ultimately, although it is becoming clear that maternal steroid hormone exposure and levels of circulating steroids in early infancy play a role in determining pubertal progression rate, precisely how and through what neuroendocrine substrates remains unclear. Perinatal steroid release from mothers, as well as reception of these signals in developing animals is also likely influenced by nutritional state even at this early stage. The role of metabolic signaling during embryonic development in establishing expression patterns required for pubertal progression will be explored below.

\section{LIKE A ROLLING STONE: KISSPEPTIN AS A STEROID HORMONE-SENSITIVE DRIVER OF GnRH SECRETION}

Research into the molecular mechanisms underlying puberty has enjoyed a renaissance over the last decade, particularly since the discovery of kisspeptin (Kiss1) and neuronal populations that express and release this peptide. While its importance to reproduction was initially unknown (Lee et al., 1996), beginning in 1999 several groups successively published findings that kisspeptin is the ligand for the orphan $G$ protein-coupled membrane receptor GPR54 in both rodents and humans (Lee et al., 1999; Kotani et al., 2001; Muir et al., 2001; Ohtaki et al., 2001), which is now also known as the kisspeptin receptor (KISS1R). In 2003 two labs demonstrated cases of humans with idiopathic hypogonadotropic hypogonadism (IHH) who had mutations in KISS1R (de Roux et al., 2003; Seminara et al., 2003) that resulted in primary dysfunction of the reproductive axis. Mutations in Kiss1 and Kiss1r were recapitulated in mice, which also displayed abnormal sexual maturation as well as decreased levels of gonadotropins and sex steroids (d'Anglemont de Tassigny et al., 2007; Dungan et al., 2007; Lapatto et al., 2007; Clarkson et al., 2008). Notably, a large majority of GnRH neurons express Kiss $1 R$ and are stimulated by kisspeptin (Irwig et al., 2004; Messager et al., 2005; Gottsch et al., 2006; Liu et al., 2008), providing initial evidence that kisspeptin directly regulates these neurons. Additionally kisspeptin can induce rapid 
LH secretion via GnRH neuronal secretion in multiple species (Gottsch et al., 2004; Dhillo et al., 2005; Messager et al., 2005; Plant, 2006; Smith et al., 2006b), further demonstrating that Kiss1 neurons directly signal to GnRH neurons (Clarkson and Herbison, 2006b). Interestingly, both Kiss1 expression and GnRH neuronal sensitivity to kisspeptin appear to be developmentally regulated, in that electrophysiological responses of adult GnRH neurons to kisspeptin differ from those recorded from juvenile, pre-pubertal neurons (Han et al., 2005).

Kisspeptin neurons are also sexually dimorphic (Kauffman et al., 2007), express sex steroid receptors such as ER $\alpha$ (Gottsch et al., 2006; Smith et al., 2006b), and are differentially responsive to sex steroid feedback (Smith et al., 2005, 2007; Gottsch et al., 2009). Two main subpopulations of Kiss1 neurons have been found in rodents: the bilateral anteroventral periventricular (AVPV) and arcuate nuclei (ARC) of the hypothalamus. In female mice Kiss 1 expression is modulated by E2 levels: high levels of AVPV kisspeptin expression correspond with elevated ovarian E2 levels, while the opposite effect is observed in the ARC, which leads to the hypothesis that the ARC and AVPV are responsible for negative and positive feedback effects of E2, respectively (Smith et al., 2005; Dungan et al., 2006; Herbison, 2008; Popa et al., 2008; Gottsch et al., 2009). Evidence in ewes also identifies the preoptic area (POA) as a critical region for Kiss1 regulation of the $\mathrm{LH}$ surge (Hoffman et al., 2011). Altered steroid hormone exposure during the developmental critical period leads to masculinization/defeminization (Kauffman et al., 2007; Gonzalez-Martinez et al., 2008) or feminization (Homma et al., 2009) of Kiss1 neurons.

\section{WHEN YOU GONNA WAKE UP: POTENTIAL ROLE OF KISSPEPTIN IN THE TRANSITION TO PUBERTY FROM THE JUVENILE PAUSE}

In addressing the role of kisspeptin in the previously posited "brake/accelerator" models of pubertal initiation, a recent report suggests that, at least in mice, kisspeptin neurons may be involved in both mechanisms (Mayer et al., 2010). During puberty, while GnRH content within the POA remains relatively constant, hypothalamic kisspeptin levels begin to rise, yet the cause of this increase is still unknown. Aside from observed disruption of kisspeptin signaling and a lack of pubertal progression seen in humans and mice with KISS1 and KISS1R mutations, further evidence for a functional link is evidenced by the temporal advancement of puberty that occurs in mice when treated with exogenous kisspeptin before puberty onset (Matsui et al., 2004; Navarro et al., 2004). Additionally, puberty can be delayed with Kiss $1 \mathrm{R}$ antagonist treatment (Pineda et al., 2009). In revisiting earlier observations on GnRH/LH activity during puberty, the question arises if Kiss1 neurons might be mediating the gradually increasing daily patterns of hormone secretion observed. Indeed, recent data suggest that in adult female mice, only on proestrus or following E2priming in ovariectomized (OVX) animals, expression levels of Kiss1 are rhythmic with peaks occurring parallel with the $\mathrm{GnRH}$ surge (Khan and Kauffman, 2011). While this has not yet been investigated throughout development, it is tempting to speculate that rhythmic Kiss1 expression and release may be responsible for the increasing diurnal rhythms of LH secretion observed in females. However, since this rhythm of expression is only evident in the presence of elevated E2 in adults, it remains unclear whether rhythmic production of Kiss1 would occur peri-pubertally.

Another very recent in vitro study suggests that a complementary rhythm of Kiss1R expression in GnRH neurons, which is also evident only during E2 positive feedback, may also exist (Tonsfeldt et al., 2011), such that incremental timed increases in Kiss1 expression and release corresponding with timed sensitivity of GnRH neurons to Kiss1 would act synergistically to drive GnRH and LH secretion in early puberty, supported by increasing ovarian E2. These daily "mini-surges" of gonadotropin secretion may then be sufficient to stimulate further follicular development and E2 production, which would then increase the amplitude of the neuroendocrine rhythms further to produce E2-stimulated positive feedback responses observed in adult females. The role of E2 in determining the effects of kisspeptin on pubertal progression appears to be significant, as highlighted by a recent study examining transgenic mice harboring a deletion of ER $\alpha$ only in Kiss1-expressing cells (Mayer et al., 2010). To achieve deletion of $\mathrm{ER} \alpha$ specifically in kisspeptin neurons, a newly generated kisspeptin-IRES-Cre (KissIC) transgenic mouse line was crossed with $\mathrm{ER} \alpha$ floxed mice $\left(\mathrm{ER} \alpha^{\text {lox/lox }}\right)$, and the double transgenic conditional knockout progeny were termed "KERKO" mice (Mayer et al., 2010). When these mice were analyzed for onset of puberty, as assessed by VO, they displayed a remarkable advancement of puberty. While their wild type littermates displayed VO on average at $\sim 29$ days, the average for KERKO mice was $\sim 13$ days. This was particularly unexpected since kisspeptin treatment in immature female rats only advanced VO by $\sim 5$ days (Navarro et al., 2004), and it suggests that the kisspeptin neurons may be controlling puberty through other signals than kisspeptin itself. It is also possible that the response to administered kisspeptin varies from KERKO mice and other genetic models due to variance in the ability of the administered peptide to reach the critical neurons or synapses, or by activating opposing systems.

Indeed, recent studies indicate that kisspeptin neurons are actually multiphenotypic, expressing a host of other neuropeptides such as galanin, met-enkephalin, neurokinin B (NKB), and dynorphin (Goodman et al., 2007; Porteous et al., 2011). In addition to early VO, KERKO mice display abnormal estrous cyclicity with anovulation, and kisspeptin expression is differentially affected in the two main sites of expression, with AVPV levels diminished but ARC levels increased (Mayer et al., 2010), in agreement with previously observed activational effects of E2 on Kiss1 expression (Kauffman et al., 2007; Kauffman, 2010a,b). As previously mentioned, data has shown that the AVPV is involved in positive feedback and it is postulated that the ARC is involved in negative feedback (Smith et al., 2005; Dungan et al., 2006; Herbison, 2008; Popa et al., 2008; Gottsch et al., 2009); these data confirm that ER $\alpha$ serves multiple purposes in these nuclei, acting as an inhibitor of kisspeptin expression in ARC neurons (the brake) and a stimulator in AVPV neurons (the accelerator).

\section{FOREVER YOUNG: COMPLEX MECHANISMS UNDERLYING PUBERTY}

Discovery of a universal initiator of puberty has proved difficult possibly due to the importance of reproduction in the survival of species. GnRH neurons are especially known for their 
heterogeneity and there are subpopulations that are still being characterized. Very few GnRH neurons are needed to successfully initiate puberty and maintain cyclicity (Gibson et al., 1984; Herbison et al., 2008), and once the system is initiated it may be able to maintain itself. Indeed, one group reported that Kiss $1 R$-knockout female mice are still able to produce an E2-primed LH surge, suggesting additional pathways mediating E2 positive feedback on GnRH neurons (Dungan et al., 2007). Further evidence supporting redundancy in these circuits as well as calling into question the importance of the Kiss1 neurons (versus kisspeptin itself) was demonstrated in a series of neuron ablation experiments (Mayer and Boehm, 2011). The aforementioned KissIC (Mayer et al., 2010) and a GPR54-IRES-Cre (GPIC) mouse lines were used to induce cell death with diphtheria toxin A (DTA) at different ages, with surprising and somewhat difficult-to-interpret results. When the KissIC line was crossed with ROSA26-DTA mice, over $90 \%$ of kisspeptin expressing cells were removed from the hypothalamus, and presumably from peripheral tissues such as the ovaries and pituitary (where there was some reported recombination) and possibly the placenta as well. However, cell death was not confirmed by looking at other markers known to be in kisspeptin neurons, such as NKB, and controls for damage to neurons adjacent to the DTA-affected kisspeptin cells were not assessed. While these mice displayed reduced ovarian mass and some minor aberrant estrus cycles, overall they did not differ substantially from controls, displaying normal development of ovarian follicles, similar average of VO, and normal fertility and fecundity. As the expression of DTA in these mice occurs when kisspeptin in expressed developmentally, an inducible diphtheria toxin receptor (iDTR) line was also used to examine ablation at different ages. Injections of diphtheria toxin post-pubertally at 20 weeks of age revealed that adult female mice require kisspeptin neurons for normal estrous cyclicity and the ability to produce offspring. Similar results were found when injection occurred at postnatal day 20 . Such phenomena are not without precedent: it appears that in both reproduction and feeding, neuronal ablation during development can be compensated for by as yet unknown mechanisms, while removing the same neurons in adulthood has severe consequences (Luquet et al., 2005). A similar set of experiments were carried out with the GPIC mice crossed to the DTA and iDTR mice. Many, but not all, GnRH neurons express GPR54, and it was reported that in the DTA paradigm GnRH neurons numbers were reduced by about $90 \%$ with an accompanying decrease of $G n R H$ mRNA levels by about 93\%, while the iDTR in the 20 week adult ablated approximately $97 \%$ of $\mathrm{GnRH}$ neurons. GPIC/R26-DTA females did have reduced ovarian mass, but whether this is attributable to the reduction in GnRH neurons or other sites of GPR54 expression is not known. Strikingly, these mice all bred successfully and had mostly normal estrous cyclicity with no differences in time of VO, suggesting either developmental compensation or the ability of the remaining $10 \%$ of $\mathrm{GnRH}$ neurons to maintain reproduction. Remarkably, the diphtheria toxin treated adult mice remained cyclic, although subfertile, with only $50 \%$ producing offspring. When contrasted with findings that kisspeptin neuron ablation in adults causes reproductive malfunction, this suggests that, while kisspeptin signaling represents one significant pathway of reproductive patency, other signals from phenotypic kisspeptin neurons may also be important.
THE LEVEE'S GONNA BREAK: THE ROLE OF METABOLIC CUES AS INITIATORS OF PUBERTY

While some studies in humans suggest correlations between the advance of pubertal maturation and the risk of reproductive cancers, type 2 diabetes, and metabolic syndrome, many of these studies were not corrected for childhood BMI and thus the data remain controversial and inconsistent (Gail et al., 1989; Petridou et al., 1996; Titus-Ernstoff et al., 2001; Frontini et al., 2003; Ahlgren et al., 2004; Riman et al., 2004; Vo and Carney, 2007; Lacey et al., 2009; Moorman et al., 2009). Indeed, these earlier results have been called into question by more current studies that controlled for BMI in childhood (Freedman et al., 2003; Must et al., 2005; Lakshman et al., 2008). However, a recent report on a large population of Norwegian women found that, even when data were adjusted for BMI, there was a strong inverse relationship between mortality and age at menarche (Jacobsen et al., 2007), which suggests that other factors may contribute to an increased risk of mortality with low age at menarche. Beyond possible physiological abnormalities, early puberty is also associated with significant psychosocial issues. In addition to increased rates of depression and anxiety in girls with early onset puberty (Siegel et al., 1999; Stice et al., 2001; Ge et al., 2003; Kaltiala-Heino et al., 2003; Blumenthal et al., 2009; Conley and Rudolph, 2009; Reardon et al., 2009), increases in delinquent behavior, smoking, and early sexual experiences have been reported in both girls and boys (Johansson and Ritzen, 2005; Ostovich and Sabini, 2005; van Jaarsveld et al., 2007). Some studies point to these problems persisting into adulthood, along with lower quality of life, higher rates of eating disorders, lower academic achievement, and higher rates of substance abuse (Graber et al., 2004; Johansson and Ritzen, 2005; Michaud et al., 2006; Zehr et al., 2007). In light of the established and potential detrimental effects of both early puberty and disruption of fertility, understanding the metabolic factors controlling puberty and reproductive maturation and function remains crucial.

Due in part to the connection of early puberty onset and overweight/obesity, considerable research over the last 5 years investigated the link between metabolism, kisspeptin, and reproduction. One such potential connection is leptin, a circulating hormone secreted by adipocytes in proportion to body fat stores thereby acting as an adiposity signal (Cummings and Schwartz, 2003; Farooqi and O'Rahilly, 2005). In addition to the exciting results of leptin replacement therapy on obesity in people with congenital leptin deficiency (Schwartz et al., 2000; Farooqi and O'Rahilly, 2005), leptin therapy can also be effective at treating some types of infertility. While many patients reporting congenital leptin deficiency began leptin treatment as pre-pubertal children, one study reported on adult subjects who all displayed hypogonadotropic hypogonadism, although there was one case of possible spontaneous pubertal development after an approximate 20 year delay (Ozata et al., 1999). This holds true for mice with congenital leptin deficiency $(o b / o b)$ or leptin receptor mutations $(d b / d b)$. These mice remain perpetually pre-pubertal with incomplete reproductive organ development and low LH levels (Swerdloff et al., 1976; Coleman, 1978; Zhang et al., 1994; Tartaglia et al., 1995), and leptin treatment in $o b / o b$ mice restores the maturation of reproductive organs and fertility while weight loss alone cannot induce these changes (Barash et al., 1996; Chehab et al., 1996, 1997; Mounzih 
et al., 1997; Cunningham et al., 1999; Chehab, 2000). In younger children, leptin therapy has enabled normal pubertal progression without causing early onset puberty (Farooqi et al., 1999, 2002), suggesting that while leptin is permissive for pubertal progression, it does not serve as a lone initiation signal for puberty. Leptin has also been used to restore menstruation in women with hypothalamic amenorrhea and lipodystrophy (Welt et al., 2004; Musso et al., 2005; Chou et al., 2011). Other studies in mice demonstrated that supraphysiological leptin levels can accelerate the onset of puberty to a limited extent (Ahima et al., 1997; Yura et al., 2000).

Leptin binds to receptors in multiple areas of the brain (Balthasar, 2006), including the ARC, which also houses Kiss1 neurons. It has been demonstrated that the active form of the leptin receptor ( $L e p R b$, also known as $O b-R b)$ is not expressed in GnRH neurons themselves (Finn et al., 1998; Quennell et al., 2009), but is present in a subpopulation of Kiss1 neurons in the ARC, although the reported extent of this co-expression varies widely (Smith et al., 2006a; Cravo et al., 2011; Louis et al., 2011; True et al., 2011). Additionally, hypothalamic Kiss1 mRNA levels are reduced in ob/ob mice (Smith et al., 2006a; Quennell et al., 2011) and streptozotocin-induced diabetic rats (Castellano et al., 2006, 2009). Leptin was able to partially restore Kiss 1 levels in $o b / o b$ mice (Smith et al., 2006a) and fully in diabetic rats (Castellano et al., 2006). Fasting and undernutrition reduce Kiss1 expression and alter reproductive function, and these defects can be rescued by exogenous kisspeptin administration (Castellano et al., 2005; Roa et al., 2008). A recent study investigating the effects of overnutrition and undernutrition on kisspeptin expression and pubertal onset used female rats in varying litter sizes to achieve postnatal underfed, normal fed, and overfed models (Castellano et al., 2011). Overfeeding resulted in increased body weight, earlier onset of puberty (as measured by VO), and increased leptin and hypothalamic Kiss 1 expression, while opposite effects were seen in the underfed rats, along with lower weight ovaries and uteri. Immunohistochemistry for Kiss 1 showed lower kisspeptin in the ARC in the underfed rats and increased kisspeptin in the AVPV of overfed rats, but when peri-pubertal rats were challenged with central administration of $\mathrm{Kp}-10$, all groups responded similarly. As noted in the study, litter size manipulations may have changed additional signals (Knox et al., 2009; Kinsey-Jones et al., 2010) and alterations of other peripheral hormones may have also affected Kiss1 expression and pubertal timing (Tena-Sempere, 2008; Forbes et al., 2009). Whether this demonstrates a causative relationship or only the ability of kisspeptin to both be affected by and bypass the underlying causes of reproductive defects remains a key question.

It was previously reported using double-label in situ hybridization (ISH) that about $40 \%$ of the Kiss 1 expressing neurons in the ARC also expressed $L e p R b$ (Smith et al., 2006a), but three recent studies have not found such high levels of co-localization. Citing issues with sensitivity of $L e p R b$ mRNA, the first study used LepRbeGFP mice to examine co-localization of LepRb with GnRH and Kiss1 in female mice (Louis et al., 2011). In agreement with earlier reports (Finn et al., 1998; Quennell et al., 2009), no co-localization of LepRb and GnRH was observed, but using a trans-synaptic tracer (wheat germ agglutinin, WGA), experimenters determined that GnRH neurons receive input from nearby LepRb-eGFP neurons. However, they did not observe high levels of Kiss1/LepRb co-localization. Kisspeptin immunoreactivity (Kp-ir) did not colocalize with LepRb-eGFP in the AVPV, and no co-localization of leptin-induced STAT3 phosphorylation (pSTAT3-ir) with Kp-ir in the POA of sheep was noted. Due to difficulties using Kp-ir in the ARC, even with colchicine treatment, NKB was used as a marker. Rather than the $40 \%$ co-localization in the ARC seen by ISH, only 5-6\% NKB/LepRb-eGFP co-localization was observed. Many other cell types in the ARC robustly express LepRb, and using WGA as a tracer it was observed that at least some of these LepRb neurons lay in close contact with Kiss1 neurons also in the ARC. The second study used a new line of Kiss1-Cre mice crossed with GFP and $\beta \mathrm{Gal}$ reporter lines to mark kisspeptin neurons (Cravo et al., 2011). Using pSTAT3-ir to mark leptin responsive cells, no co-localization was reported in the AVPV of these mice. pSTAT3-ir/Kiss1-Cre co-localization in the ARC was seen in $\sim 10$ $15 \%$ of Kiss 1 -Cre neurons (depending on rostral-to-caudal level), which translated to between 2 and $10 \%$ of the pSTAT3-ir neurons (depending again on level), as there were more pSTAT3-ir positive cells in the ARC. A third study explored activation of three markers of leptin signaling: pSTAT3 and 5 as well as pS6 as a marker of mTORC1 pathway signaling in kisspeptin neurons, using Kp-ir (Quennell et al., 2011). While leptin injections in fasted mice activated all of these pathways in the AVPV, ARC, and other areas, experimenters observed no co-localization of Kpir with leptin-induced signals in the AVPV and were unable to determine co-localization in the ARC due to the dense kisspeptin fiber network. The disparity between these studies may be due to differing techniques, but the results of the newer studies bring into question how much of a direct effect leptin has on kisspeptin neurons, and how much of the effect of leptin on reproduction must be afferent to the kisspeptin neurons or through different cell pathways altogether.

This question is currently being examined. Now that multiple Kiss1-Cre mouse lines have been created (Mayer et al., 2010; Cravo et al., 2011; Gottsch et al., 2011), they can be used as powerful tools to dissect the importance of gene pathways in these neurons. A recent study used one of these lines to delete LepRb from the kisspeptin neurons (Donato et al., 2011). After gonadectomy to intensify the expression of Kiss 1 mRNA in the ARC, leptin treatment was used in conjunction with pSTAT3-ir to observe leptin signaling. Using this technique, approximately $20 \%$ colocalization was seen in the ARC of wild type males and $13 \%$ in wild type females, and this was reduced to $5 \%$ in the conditional homozygous knockouts (Kiss1-Cre/LepRb ${ }^{\text {flox/flox }}$ ), which suggests significant but incomplete deletion of LepRb from Kiss1 neurons. These mice exhibited no defects in age at VO, days to pregnancy, or fecundity, and they conclude that leptin signaling in these neurons is unnecessary for reproduction. Due to the fact that partial leptin signaling was still present in these mice, perhaps a stronger demonstration of this could have been achieved by reactivating the LepRb in Kiss1 neurons, as was done in the ventral premammillary nucleus (PMV) later in the same publication. Notably, bilateral lesions of the PMV did not prevent normal food intake and body weight responses to leptin injections, but sexual maturation was disrupted by these lesions. Restoration of LepRb in the PMV rescued puberty, improved fertility and normalized GnRH content, although it did not affect body weight and food intake. 
PMV neurons with LepRbs innervate both AVPV Kiss1 neurons and GnRH terminals, thus providing a potential pathway for leptin to regulate both Kiss1 and GnRH. An earlier study in juvenile primates demonstrated that lesions proximal to this area resulted in precocious puberty, implicating this hypothalamic region not only in metabolic sensing, but also in the regulation of pubertal timing (Windsor-Engnell et al., 2007). Another group examined the interactions of kisspeptin and leptin using a long-term calorie restriction model in OVX female rats with or without low levels of E2 replacement (True et al., 2011). Forty percent of caloric restriction (CR) decreased leptin levels in both calorie restricted groups, with lower leptin levels observed in OVX animals. Surprisingly, LH levels were significantly decreased with CR only in E2-treated rats, suggesting that $\mathrm{LH}$ inhibition by $\mathrm{CR}$ requires the actions of E2. Kiss1 mRNA in the ARC was decreased with calorie restriction regardless of E2 treatment, but AVPV Kiss1 was unchanged in both groups. However, physiological doses of leptin had no effect on ARC Kiss1 levels and, strangely, AVPV Kiss1 actually decreased. Due to considerable variability in LH levels in rats with $40 \% \mathrm{CR}$, treatments were repeated with $50 \% \mathrm{CR}$, but only in OVX + E2 animals this time. Greater loss of body weight and reduced $\mathrm{LH}$ variability were observed, suggesting that a certain amount of weight loss is necessary to inhibit LH. In this paradigm both ARC and AVPV Kiss1 levels were decreased and were not restored by $72 \mathrm{~h}$ leptin treatment. While these data conflict with previous studies showing the ability of leptin to rescue Kiss1 levels (Castellano et al., 2006; Smith et al., 2006a), the authors argue that this is due to a difference of pharmacological versus physiological dosing. The same group examined whether there was significant leptin signaling in the Kiss1 neurons in the ARC, and while they too saw high levels of pSTAT3-ir in the ARC of leptin treated animals, there were very few co-localized Kp-ir/pSTAT3-ir cells, in agreement with previously discussed recent results (Cravo et al., 2011; Louis et al., 2011). While the results from Donato et al. (2011) imply an indirect mechanism for the involvement of leptin with kisspeptin signaling and reproduction, the study by True et al. (2011) suggests that leptin may not be the metabolic signal integrating reproduction and nutrition, rather, another candidate or candidates such as glucose, insulin, ghrelin, and neuropeptide $Y$ (NPY) might instead represent the elusive missing link. Regardless, future studies teasing apart the neuronal circuitry will be aided by new transgenic mouse lines such as the recently created Kiss1-Cre (Mayer et al., 2010; Cravo et al., 2011).

\section{TANGLED UP IN CUE: ENDOGENOUS CENTRAL AND PERIPHERAL CLOCKS AS POSSIBLE LINKS BETWEEN METABOLISM AND REPRODUCTION}

Although many studies in human and animal models suggest that achievement of a threshold body mass is important for pubertal initiation, much of these data are correlative, and studies in rodents investigating this "body fat hypothesis" have found only limited evidence of such a link (Bronson and Manning, 1991). Due to this, some investigators have proposed that the neuroendocrine control of reproduction converging at the level of $\mathrm{GnRH}$ neurons is instead responsive to rapid nutritional changes, using multiple metabolic cues to communicate changes to the hypothalamus (Wade and Schneider, 1992; Wade et al., 1996). This "metabolic fuels hypothesis" posits that availability of oxidizable substrates may represent the crucial signal to the hypothalamic circuitry regulating reproduction, and that even obesity-related infertility may result from a lack of usable calories, as hyperphagic adipocytes may sequester oxidizable fuels required for fertility. A number of experimental models resulting in glucoprivation result in rapid declines in LH secretion, suggesting that hypothalamic reproductive circuits are extremely sensitive to hypoglycemia, such that both estrous cyclicity in adults as well as timing of pubertal initiation would be altered by nutritional state (Schneider et al., 1993, 2000). The neuronal circuitry responsible for communicating these metabolic changes to $\mathrm{GnRH}$ neurons is incompletely characterized, but studies implicate a role for hepatic signals transmitted via vagal innervation of the area postrema/nucleus tractus solitaries (Wade et al., 1996). It is currently unclear if these signals are transduced to communicate with GnRH neurons via Kiss1-expressing populations.

While recent studies suggest that kisspeptin is a required player in pubertal initiation, and that leptin may also contribute to this process, it still remains unclear what other peripheral factors may play a role in conferring the signal of metabolic readiness to Kiss 1 neurons and/or to the rest of the neuroendocrine reproductive axis. Furthermore, the observation of daily leptin (Sinha et al. 1996; Palmert et al., 1998; Kasa-Vubu et al., 2002) and adiponectin (Shea et al., 2005; Gomez-Abellan et al., 2010; Scheer et al., 2010) rhythms in peri-pubertal animals and humans in conjunction with a growing awareness of the contribution of circadian oscillators in both metabolic control and reproduction suggest that endogenous clocks may play a role in the initiation of puberty. If, indeed, developing circadian oscillators functioning at single or multiple points in the reproductive axis are required for eventual maturation of the positive feedback effects of E2 in females, it is important to examine, then, how human lifestyle patterns of nutrition both perinatally and during juvenile development might affect these central and peripheral oscillators. Due to the recursive relationship between cellular and organismal metabolic regulators and the circadian clock (reviewed in detail in Asher and Schibler, 2011), a recent study used a model of aberrant metabolic state to determine what effects metabolic abnormalities may exert on core clock and clock-controlled gene expression patterns. Ando et al. (2011) found that ob/ob mice lacking leptin production exhibited long-lasting alterations in clock gene expression patterns that began early in development and persisted into adulthood. Interestingly, clock gene expression patterns in the SCN were unaltered in $o b / o b$ mice, but expression patterns in the liver and adipose tissue were severely blunted, even in adults raised on a low-calorie diet (Ando et al., 2011). Short-term (1 week) administration of leptin was able to rescue clock gene cycling in the liver, but not as dramatically as in adipose tissue (Ando et al., 2011), which implies that exposure to this adipose-derived factor throughout development is required for function of peripheral clocks. Reproductive hormone secretion patterns were not examined in this study; however, previous work has established that $o b / o b$ mice exhibit delayed puberty and diminished reproductive capacity, both of which can be reversed by leptin administration. Leptin itself is secreted from adipose cells with a circadian rhythm (Sinha et al., 1996; Palmert et al., 1998; Kasa-Vubu et al., 2002; 
Wilson et al., 2003), suggesting that this adipokine may act as a permissive factor for pubertal development by maintaining oscillators throughout the reproductive axis. It is unknown if molecular clock oscillations in either Kiss 1 or GnRH neurons are affected in leptin-deficient mice, but studies described below demonstrate that metabolic signals can dramatically affect hypothalamic gene expression patterns. Deviations from a normal pattern of leptin production, such as those encountered in obesity, may then lead to dysregulation of normal hypothalamic gene expression patterns required for timing puberty. It is clear from other work that restricted feeding paradigms, which have no effect on oscillators within the light-entrainable SCN, can drive circadian oscillations of gene expression in peripheral tissues, even in the absence of leptin signaling, as demonstrated by the reinstatement of clock cycling in the liver of $d b / d b$ mice subjected to timed restricted feeding (Kudo et al., 2004).

There is considerable evidence in both human and rodent models that perinatal nutrition can also exert later effects on both metabolism and reproduction. Human mothers exposed to low-protein, high-carbohydrate diets often have low birthweight babies that exhibit accelerated growth in the juvenile period compared to children with proper perinatal nutrition (Ibanez et al., 1998a, 2001). This is mimicked in rats: low-protein fed dams give birth to pups with lower weight, which soon overtake their normally fed counterparts in food intake (Coupe et al., 2009; Tarry-Adkins et al., 2009). Additionally, the effects of maternal undernutrition have profound effects on gene expression rhythms in the hypothalamus, many of which persist into adulthood. A recent study found that these core clock gene expression patterns were blunted, and many other clock-controlled genes important for metabolic regulation, including orexigenic and anorexigenic peptides such as NPY, POMC, agouti-related peptide (AgRP), and cocaine and amphetamine-regulated transcript (CART), were also altered (Orozco-Solis et al., 2011). Additionally, maternal undernutrition resulted in profound alterations in expression patterns of fatty acid synthase, PGC1 $\alpha$, and glucokinase in the liver of pups (Orozco-Solis et al., 2011), demonstrating that perinatal nutrition is important for clock gene cycling in both central and peripheral clocks. Regarding human health, a combination of poor perinatal nutrition and childhood obesity would appear to have profound effects on gene expression patterning in both the neuroendocrine hypothalamus and peripheral organs, which could in turn impact timing mechanisms controlling duration of juvenile pause and pubertal initiation.

Enhancing the complex picture of metabolic regulation, more recent studies have added further links between cellular metabolism, circadian clock machinery, and neuroendocrine control of reproduction. It was recently found that the nutrient-sensitive adenosine monophosphate kinase (AMPK) likely plays a major role in both metabolic signaling in the liver and adipose tissues (Mor and Unnikrishnan, 2011), as well as a role in controlling $\mathrm{GnRH}$ secretion in response to adipocyte-derived factors such as adiponectin (Cheng et al., 2011). Additionally, AMPK affects endogenous circadian clocks by phosphorylation of negative feedback components PER and CRY, leading to the rapid degradation of these proteins in the clock loop (Lamia et al.,
2009). AMPK nuclear accumulation and activity is circadian, and is likely an important regulator integrating cellular metabolism with the clock (Um et al., 2011). Interestingly, GnRH neurons and immortalized GT1-7 cells express AMPK subunits, and the AMPK activators metformin and AICAR have direct effects on GnRH secretory rate (Coyral-Castel et al., 2008; Roland and Moenter, 2011). Indeed, adiponectin inhibits GnRH secretion through an AMPK-mediated pathway (Cheng et al., 2011), and activation of this kinase decreases GnRH secretion associated with perinatal androgen exposure (Roland and Moenter, 2011), which induces a PCOS-like phenotype. Prenatal testosterone exposure results in an overactive $\mathrm{GnRH}$ pulse generator, with isolated $\mathrm{GnRH}$ neurons displaying an increased basal firing rate, an effect reversed by AMPK activation (Roland and Moenter, 2011).

\section{SLOW TRAIN: CONCLUSIONS AND FUTURE CONSIDERATIONS}

If, indeed, appropriate timing of puberty and regulation of the reproductive axis in adults requires functioning circadian oscillators at multiple points, a model of metabolic signaling can be envisioned to integrate these disparate players. Under normal conditions of perinatal steroid and nutrition exposure, the neuroendocrine hypothalamus of juvenile animals would experience antiphasic rhythms of leptin and adiponectin, both of which serve to signal metabolic status in a rhythmic pattern, with leptin acting as a permissive cue and adiponectin potentially preventing over-activation of the GnRH pulse generator. Priming of $\mathrm{GnRH}$ and Kisspeptin neurons with these rhythmic signals, along with the development of oscillators within these neuronal populations, could then lead to gradual increases in $\mathrm{GnRH} / \mathrm{LH}$ secretion also with a circadian rhythmicity, as has been observed. Increases in neuroendocrine output would begin to prime the gonads, and in females, ovarian estrogen could potentially drive these hypothalamic rhythms toward positive feedback responsiveness, resulting in ovulation. In adulthood, these rhythms would then only be evident under elevated E2 exposure, driving ovulation with an infradian ( $>24 \mathrm{~h}$ ) rhythm appropriate with follicular development and sexual behavior. Conversely, metabolic disruptions resulting from prenatal undernutrition and childhood obesity would alter this process at multiple points. Levels of leptin and adiponectin would increase concomitant with increased fat mass, and metabolic syndrome associated with obesity and sedentary behavior would decrease activation of AMPK in multiple cell types, thus blunting core clock and clock-controlled gene expression patterns throughout the reproductive axis. This model remains purely conjectural, however, and will require extensive studies that examine gene expression oscillations in reproductive cell types throughout the juvenile pause and puberty, and investigation into how these patterns are altered by obesity and other metabolic dysfunction.

While endogenous clocks likely play a role in physiological processes governing complex behaviors and higher cognitive function, as well as in fundamental molecular mechanisms controlling cellular respiration, chromatin remodeling, and oxidative damage and repair, precisely how these clocks exert their effects by controlling rhythms of transcription, translation, and protein abundance remains unclear, and efforts remain ongoing to include them in 
existing conceptual models. Future work will be necessary to determine how peripheral metabolic signals, gonadal steroid hormones, and genetically programmed developmental processes converge to precipitate one of the most crucial processes in mammals - that of

\section{REFERENCES}

Adam, C. L., Moar, K. M., Logie, T. J., Ross, A. W., Barrett, P., Morgan, P. J., and Mercer, J. G. (2000). Photoperiod regulates growth, puberty and hypothalamic neuropeptide and receptor gene expression in female Siberian hamsters. Endocrinology 141, 4349-4356.

Ahima, R. S., Dushay, J., Flier, S. N., Prabakaran, D., and Flier, J. S. (1997). Leptin accelerates the onset of puberty in normal female mice. $J$. Clin. Invest. 99, 391-395.

Ahlgren, M., Melbye, M., Wohlfahrt, J., and Sorensen, T. I. (2004). Growth patterns and the risk of breast cancer in women. N. Engl. J. Med. 351, 1619-1626.

Aksglaede, L., Sorensen, K., Petersen, J. H., Skakkebaek, N. E., and Juul, A. (2009). Recent decline in age at breast development: the Copenhagen Puberty Study. Pediatrics 123, e932-e939.

Albertsson-Wikland, K., Rosberg, S., Lannering, B., Dunkel, L., Selstam, G., and Norjavaara, E. (1997). Twenty-four-hour profiles of luteinizing hormone, folliclestimulating hormone, testosterone, and estradiol levels: a semilongitudinal study throughout puberty in healthy boys. J. Clin. Endocrinol. Metab. 82, 541-549.

Aloi, J. A., Bergendahl, M., Iranmanesh, A., and Veldhuis, J. D. (1997). Pulsatile intravenous gonadotropin-releasing hormone administration averts fastinginduced hypogonadotropism and hypoandrogenemia in healthy, normal weight men. J. Clin. Endocrinol. Metab. 82, 1543-1548.

Alvarez, J. D., Hansen, A., Ord, T., Bebas, P., Chappell, P. E., Giebultowicz, J. M., Williams, C., Moss, S., and Sehgal, A. (2008). The circadian clock protein BMAL1 is necessary for fertility and proper testosterone production in mice. J. Biol. Rhythms 23, 26-36.

Ando, H., Kumazaki, M., Motosugi, Y., Ushijima, K., Maekawa, T., Ishikawa, E., and Fujimura, A. (2011). Impairment of peripheral circadian clocks precedes metabolic abnormalities in ob/ob mice. Endocrinology 152, 1347-1354.

Andrews, W. W., Advis, J. P., and Ojeda, S. R. (1981). The maturation of estradiol-negative feedback in female rats: evidence that the resetting of the hypothalamic "gonadostat" does not precede the first preovulatory surge of gonadotropins. Endocrinology 109, 2022-2031.

Ankarberg-Lindgren, C., and Norjavaara, E. (2004). Changes of diurnal rhythm and levels of total and free testosterone secretion from pre to late puberty in boys: testis size of $3 \mathrm{ml}$ is a transition stage to puberty. Eur. J. Endocrinol. 151, 747-757.

Apter, D., Butzow, T. L., Laughlin, G. A., and Yen, S. S. (1993). Gonadotropinreleasing hormone pulse generator activity during pubertal transition in girls: pulsatile and diurnal patterns of circulating gonadotropins. J. Clin. Endocrinol. Metab. 76, 940-949.

Asher, G., and Schibler, U. (2011). Crosstalk between components of circadian and metabolic cycles in mammals. Cell Metab. 13, 125-137.

Balthasar, N. (2006). Genetic dissection of neuronal pathways controlling energy homeostasis. Obesity (Silver Spring) 14(Suppl. 5), 222S-227S.

Barash, I. A., Cheung, C. C., Weigle, D. S., Ren, H., Kabigting, E. B., Kuijper, J. L., Clifton, D. K., and Steiner, R. A. (1996). Leptin is a metabolic signal to the reproductive system. Endocrinology 137, 3144-3147.

Bebas, P., Goodall, C. P., Majewska, M., Neumann, A., Giebultowicz, J. M., and Chappell, P. E. (2008). Circadian clock and output genes are rhythmically expressed in extratesticular ducts and accessory organs of mice. FASEB J. 23, 523-533.

Bergendahl, M., Perheentupa, A., and Huhtaniemi, I. (1991). Starvationinduced suppression of pituitarytesticular function in rats is reversed by pulsatile gonadotropin-releasing hormone substitution. Biol. Reprod. 44, 413-419.

Biro, F. M., Galvez, M. P., Greenspan, L. C., Succop, P. A., Vangeepuram, N., Pinney, S. M., Teitelbaum, S., Windham, G. C., Kushi, L. H., and Wolff, M. S. (2010). Pubertal assessment method and baseline characteristics in a mixed longitudinal study of girls. Pediatrics 126, e583-e590.

Biro, F. M., Khoury, P., and Morrison, J. A. (2006). Influence of obesity on timing of puberty. Int. J. Androl. 29, 272-277; discussion 286-290.

Biro, F. M., Mcmahon, R. P., StriegelMoore, R., Crawford, P. B., Obarzanek, E., Morrison, J. A.,

sexual maturation. More basic research in this area will be better able to inform studies of how trends in human behavior governing nutrition and activity may exert broader impacts on our developmental physiology as a whole.

Barton, B. A., and Falkner, F. (2001) Impact of timing of pubertal maturation on growth in black and white female adolescents: The National Heart, Lung, and Blood Institute Growth and Health Study. J. Pediatr. 138, 636-643.

Bluher, S., and Mantzoros, C. S. (2007). Leptin in reproduction. Curr. Opin. Endocrinol. Diabetes Obes. 14, 458-464.

Blumenthal, H., Leen-Feldner, E. W., Trainor, C. D., Babson, K. A., and Bunaciu, L. (2009). Interactive roles of pubertal timing and peer relations in predicting social anxiety symptoms among youth. J. Adolesc. Health 44, 401-403.

Boden, M. J., and Kennaway, D. J. (2004). Reproductive consequences of circadian dysfunction: fertility in the Bmall null mouse. Reprod. Fertil. Dev. 16, 280.

Boden, M. J., and Kennaway, D J. (2005). Reproduction in the arrhythmic Bmall knockout mouse. Reprod. Fertil. Dev. 17, 126.

Boden, M. J., and Kennaway, D. J. (2006). Circadian rhythms and reproduction. Reproduction 132, 379-392.

Bronson, F. H., and Manning, J. M. (1991). The energetic regulation of ovulation: a realistic role for body fat. Biol. Reprod. 44, 945-950.

Butler, M. P., Trumbull, J. J., Turner, K. W., and Zucker, I. (2007). Timing of puberty and synchronization of seasonal rhythms by simulated natural photoperiods in female Siberian hamsters. Am. J. Physiol. Regul. Integr. Comp. Physiol. 293, R413R420.

Caraty, A., Evans, N. P., Fabre-Nys, C. J., and Karsch, E. J. (1995). The preovulatory gonadotrophin-releasing hormone surge: a neuroendocrine signal for ovulation. J. Reprod. Fertil. Suppl. 49, 245-255.

Castellano, J. M., Bentsen, A. H. Sanchez-Garrido, M. A., Ruiz-Pino, F., Romero, M., Garcia-Galiano, D., Aguilar, E., Pinilla, L., Dieguez, C., Mikkelsen, J. D., and Tena-Sempere, M. (2011). Early metabolic programming of puberty onset: impact of changes in postnatal feeding and rearing conditions on the timing of puberty and development of the hypothalamic kisspeptin system. Endocrinology 152, 3396-3408.
Castellano, J. M., Navarro, V. M., Fernandez-Fernandez, R., Nogueiras, R., Tovar, S., Roa, J., Vazquez, M. J., Vigo, E., Casanueva, F. F., Aguilar, E., Pinilla, L., Dieguez, C., and Tena-Sempere, M. (2005). Changes in hypothalamic KiSS-1 system and restoration of pubertal activation of the reproductive axis by kisspeptin in undernutrition. Endocrinology 146, 3917-3925.

Castellano, J. M., Navarro, V. M., Fernandez-Fernandez, R., Roa, J., Vigo, E., Pineda, R., Dieguez, C., Aguilar, E., Pinilla, L., and Tena-Sempere, M. (2006). Expression of hypothalamic KiSS-1 system and rescue of defective gonadotropic responses by kisspeptin in streptozotocininduced diabetic male rats. Diabetes 55, 2602-2610.

Castellano, J. M., Navarro, V. M., Roa, J., Pineda, R., Sanchez-Garrido, M. A., Garcia-Galiano, D., Vigo, E., Dieguez, C., Aguilar, E., Pinilla, L., and Tena-Sempere, M. (2009). Alterations in hypothalamic KiSS1 system in experimental diabetes: early changes and functional consequences. Endocrinology 150, 784-794.

Chappell, P. E., White, R. S., and Mellon, P. L. (2003). Circadian gene expression regulates pulsatile gonadotropin-releasing hormone (GnRH) secretory patterns in the hypothalamic GnRH-secreting GT1-7 cell line. J. Neurosci. 23, 11202-11213.

Chehab, F. F. (2000). Leptin as a regulator of adipose mass and reproduction. Trends Pharmacol. Sci. 21, 309-314.

Chehab, F. F., Lim, M. E., and Lu, R. (1996). Correction of the sterility defect in homozygous obese female mice by treatment with the human recombinant leptin. Nat. Genet. 12, 318-320.

Chehab, F. F., Mounzih, K., Lu, R., and Lim, M. E. (1997). Early onset of reproductive function in normal female mice treated with leptin. Science 275, 88-90.

Cheng, X. B., Wen, J. P., Yang, J., Yang, Y., Ning, G., and Li, X. Y. (2011). GnRH secretion is inhibited by adiponectin through activation of AMP-activated protein kinase and extracellular signal-regulated kinase. Endocrine 39, 6-12. 
Chongthammakun, S., Claypool, L. E., and Terasawa, E. (1993). Ovariectomy increases in vivo luteinizing hormone-releasing hormone release in pubertal, but not prepubertal, female rhesus monkeys. J. Neuroendocrinol. 5, 41-50.

Chongthammakun, S., and Terasawa, E. (1993). Negative feedback effects of estrogen on luteinizing hormonereleasing hormone release occur in pubertal, but not prepubertal, ovariectomized female rhesus monkeys. Endocrinology 132, 735-743.

Chou, S. H., Chamberland, J. P., Liu, X., Matarese, G., Gao, C., Stefanakis, R., Brinkoetter, M. T., Gong, H., Arampatzi, K., and Mantzoros, C. S. (2011). Leptin is an effective treatment for hypothalamic amenorrhea. Proc. Natl. Acad. Sci. U.S.A. 108, 6585-6590.

Clarkson, J., d'Anglemont de Tassigny, X., Moreno, A. S., Colledge, W. H., and Herbison, A. E. (2008). Kisspeptin-GPR54 signaling is essential for preovulatory gonadotropin-releasing hormone neuron activation and the luteinizing hormone surge. J. Neurosci. 28, 8691-8697.

Clarkson, J., and Herbison, A. E. (2006a). Development of GABA and glutamate signaling at the $\mathrm{GnRH}$ neuron in relation to puberty. Mol. Cell. Endocrinol. 254-255, 32-38.

Clarkson, J., and Herbison, A. E. (2006b). Postnatal development of kisspeptin neurons in mouse hypothalamus; sexual dimorphism and projections to gonadotropinreleasing hormone neurons. Endocrinology 147, 5817-5825.

Coleman, D. L. (1978). Obese and diabetes: two mutant genes causing diabetes-obesity syndromes in mice. Diabetologia 14, 141-148.

Conley, C. S., and Rudolph, K. D. (2009). The emerging sex difference in adolescent depression: interacting contributions of puberty and peer stress. Dev. Psychopathol. 21, 593-620.

Coupe, B., Grit, I., Darmaun, D., and Parnet, P. (2009). The timing of "catch-up growth" affects metabolism and appetite regulation in male rats born with intrauterine growth restriction. Am. J. Physiol. Regul. Integr. Comp. Physiol. 297, R813R824.

Coyral-Castel, S., Tosca, L., Ferreira, G., Jeanpierre, E., Rame, C., Lomet, D., Caraty, A., Monget, P., Chabrolle, C., and Dupont, J. (2008). The effect of AMP-activated kinase activation on gonadotrophin-releasing hormone secretion in GT1-7 cells and its potential role in hypothalamic regulation of the oestrous cyclicity in rats. J. Neuroendocrinol. 20, 335-346.

Cravo, R. M., Margatho, L. O., OsborneLawrence, S., Donato, J. Jr., Atkin, S., Bookout, A. L., Rovinsky, S., Frazao, R., Lee, C. E., Gautron, L., Zigman, J. M., and Elias, C. F. (2011). Characterization of Kiss1 neurons using transgenic mouse models. Neuroscience 173, 37-56.

Cummings, D. E., and Schwartz, M. W. (2003). Genetics and pathophysiology of human obesity. Annu. Rev. Med. 54, 453-471.

Cunningham, M. J., Clifton, D. K., and Steiner, R. A. (1999). Leptin's actions on the reproductive axis: perspectives and mechanisms. Biol. Reprod. 60, 216-222.

Daan, S., Damassa, D., Pittendrigh, C. S., and Smith, E. R. (1975). An effect of castration and testosterone replacement on a circadian pacemaker in mice (Mus musculus). Proc. Natl. Acad. Sci. U.S.A. 72, 3744-3747.

d'Anglemont de Tassigny, X., Fagg, L. A., Dixon, J. P., Day, K., Leitch, H. G., Hendrick, A. G., Zahn, D., Franceschini, I., Caraty, A., Carlton, M. B., Aparicio, S. A., and Colledge, W. H. (2007). Hypogonadotropic hypogonadism in mice lacking a functional Kiss1 gene. Proc. Natl. Acad. Sci. U.S.A. 104, 10714-10719.

Davison, K. K., Susman, E. J., and Birch, L. L. (2003). Percent body fat at age 5 predicts earlier pubertal development among girls at age 9. Pediatrics 111, 815-821.

de Roux, N., Genin, E., Carel, J. C., Matsuda, F., Chaussain, J. L., and Milgrom, E. (2003). Hypogonadotropic hypogonadism due to loss of function of the KiSS1-derived peptide receptor GPR54. Proc. Natl. Acad. Sci. U.S.A. 100, 10972-10976.

Debeljuk, L., Arimura, A., and Schally, A. V. (1972). Pituitary responsiveness to LH-releasing hormone in intact female rats of different ages. Endocrinology 90, 1499-1502.

Dhillo, W. S., Chaudhri, O. B., Patterson, M., Thompson, E. L., Murphy, K. G., Badman, M. K., Mcgowan, B. M., Amber, V., Patel, S., Ghatei, M.A., and Bloom, S. R. (2005). Kisspeptin54 stimulates the hypothalamicpituitary-gonadal axis in human males. J. Clin. Endocrinol. Metab. 90, 6609-6615.

Donato, J. Jr., Cravo, R. M., Frazao, R., Gautron, L., Scott, M. M., Lachey, J., Castro, I. A., Margatho, L. O., Lee, S., Lee, C., Richardson, J. A., Friedman, J., Chua, S. Jr., Coppari, R., Zigman, J. M., Elmquist, J. K., and Elias, C. F.
(2011). Leptin's effect on puberty in mice is relayed by the ventral premammillary nucleus and does not require signaling in Kiss1 neurons. J. Clin. Invest. 121, 355-368.

Dungan, H. M., Clifton, D. K., and Steiner, R. A. (2006). Minireview: kisspeptin neurons as central processors in the regulation of gonadotropin-releasing hormone secretion. Endocrinology 147, 1154-1158.

Dungan, H. M., Gottsch, M. L., Zeng, H., Gragerov, A., Bergmann, J. E., Vassilatis, D. K., Clifton, D. K., and Steiner, R. A. (2007). The role of kisspeptin-GPR54 signaling in the tonic regulation and surge release of gonadotropin-releasing hormone/luteinizing hormone. J. Neurosci. 27, 12088-12095.

Dunkel, L., Alfthan, H., Stenman, U. H., Selstam, G., Rosberg, S., and Albertsson-Wikland, K. (1992). Developmental changes in 24-hour profiles of luteinizing hormone and follicle-stimulating hormone from prepuberty to midstages of puberty in boys. J. Clin. Endocrinol. Metab. 74, 890-897.

Ebling, F. J. (2010). Photoperiodic regulation of puberty in seasonal species. Mol. Cell. Endocrinol. 324, 95-101.

Euling, S. Y., Herman-Giddens, M. E. Lee, P. A., Selevan, S. G., Juul, A., Sorensen, T. I., Dunkel, L., Himes, J. H., Teilmann, G., and Swan, S. H. (2008). Examination of US pubertytiming data from 1940 to 1994 for secular trends: panel findings. Pediatrics 121(Suppl. 3), S172-S191.

Fahrenkrug, J., Georg, B., Hannibal, J., Hindersson, P., and Gras, S. (2006). Diurnal rhythmicity of the clock genes Per1 and Per2 in the rat ovary. Endocrinology 147, 3769-3776.

Fahrenkrug, J., Hannibal, J., and Georg, B. (2008). Diurnal rhythmicity of the canonical clock genes Per1, Per2 and Bmall in the rat adrenal gland is unaltered after hypophysectomy. J. Neuroendocrinol. 20, 323-329.

Farooqi, I. S., Jebb, S. A., Langmack, G. Lawrence, E., Cheetham, C. H., Prentice, A. M., Hughes, I. A., Mccamish, M. A., and O’Rahilly, S. (1999). Effects of recombinant leptin therapy in a child with congenital leptin deficiency. N. Engl. J. Med. 341, 879-884.

Farooqi, I. S., Matarese, G., Lord, G. M., Keogh, J. M., Lawrence, E., Agwu, C., Sanna, V., Jebb, S. A., Perna, F., Fontana, S., Lechler, R. I., Depaoli, A. M., and O'Rahilly, S. (2002). Beneficial effects of leptin on obesity, T cell hyporesponsiveness, and neuroendocrine/metabolic dysfunction of human congenital leptin deficiency. J. Clin. Invest. 110, 1093-1103.

Farooqi, I. S., and O'Rahilly, S. (2005). Monogenic obesity in humans. Annu. Rev. Med. 56, 443-458.

Finn, P. D., Cunningham, M. J., Pau, K. Y., Spies, H. G., Clifton, D. K., and Steiner, R. A. (1998). The stimulatory effect of leptin on the neuroendocrine reproductive axis of the monkey. Endocrinology 139, 4652-4662.

Flegal, K. M., Carroll, M. D., Kuczmarski, R. J., and Johnson, C. L. (1998). Overweight and obesity in the United States: prevalence and trends, 1960-1994. Int. J. Obes. Relat. Metab. Disord. 22, 39-47.

Forbes, S., Li, X. F., Kinsey-Jones, J., and O'Byrne, K. (2009). Effects of ghrelin on Kisspeptin mRNA expression in the hypothalamic medial preoptic area and pulsatile luteinising hormone secretion in the female rat. Neurosci. Lett. 460, 143-147.

Foster, D. L., Karsch, F. J., Olster, D. H., Ryan, K. D., and Yellon, S. M. (1986). Determinants of puberty in a seasonal breeder. Recent Prog. Horm. Res. 42, 331-384.

Foster, D. L., and Ryan, K. D. (1979). Endocrine mechanisms governing transition into adulthood: a marked decrease in inhibitory feedback action of estradiol on tonic secretion of luteinizing hormone in the lamb during puberty. Endocrinology 105, 896-904.

Foster, D. L., and Ryan, K. D. (1981). Endocrine mechanisms governing transition into adulthood in female sheep. J. Reprod. Fertil. Suppl. 30, 75-90.

Foster, D. L., Yellon, S. M., and Olster, D. H. (1985). Internal and external determinants of the timing of puberty in the female. J. Reprod. Fertil. 75, 327-344.

Freedman, D. S., Khan, L. K., Serdula, M. K., Dietz, W. H., Srinivasan, S. R., and Berenson, G. S. (2003). The relation of menarcheal age to obesity in childhood and adulthood: the Bogalusa Heart Study. BMC Pediatr. 3, 3. doi:10.1186/1471-2431-3-3

Frisch, R. E., and McArthur, J. W. (1974). Menstrual cycles: fatness as a determinant of minimum weight for height necessary for their maintenance or onset. Science 185, 949-951.

Froguel, P., and Boutin, P. (2001). Genetics of pathways regulating body weight in the development of obesity in humans. Exp. Biol. Med. (Maywood) 226, 991-996. 
Frontini, M. G., Srinivasan, S. R., and Berenson, G. S. (2003). Longitudinal changes in risk variables underlying metabolic Syndrome X from childhood to young adulthood in female subjects with a history of early menarche: the Bogalusa Heart Study. Int. J. Obes. Relat. Metab. Disord. 27, 1398-1404.

Gail, M. H., Brinton, L. A., Byar, D. P., Corle, D. K., Green, S. B., Schairer, C., and Mulvihill, J. J. (1989). Projecting individualized probabilities of developing breast cancer for white females who are being examined annually. $J$. Natl. Cancer Inst. 81, 1879-1886.

Gall, A. J., Todd, W. D., Ray, B., Coleman, C. M., and Blumberg, M. S. (2008). The development of day-night differences in sleep and wakefulness in Norway rats and the effect of bilateral enucleation. J. Biol. Rhythms 23, 232-241.

Ge, X., Kim, I. J., Brody, G. H., Conger, R. D., Simons, R. L., Gibbons, F. X., and Cutrona, C. E. (2003). It's about timing and change: pubertal transition effects on symptoms of major depression among African American youths. Dev. Psychol. 39, 430-439.

Gibson, M. J., Krieger, D. T., Charlton, H. M., Zimmerman, E. A., Silverman, A. J., and Perlow, M. J. (1984). Mating and pregnancy can occur in genetically hypogonadal mice with preoptic area brain grafts. Science 225, 949-951.

Gillespie, J. M., Chan, B. P., Roy, D., Cai, F., and Belsham, D. D. (2003). Expression of circadian rhythm genes in gonadotropin-releasing hormone-secreting GT1-7 neurons. Endocrinology 144, 5285-5292.

Gomez-Abellan, P., Gomez-Santos, C., Madrid, J. A., Milagro, F. I., Campion, J., Martinez, J. A., Ordovas, J. M., and Garaulet, M. (2010). Circadian expression of adiponectin and its receptors in human adipose tissue. Endocrinology 151, 115-122.

Gonzalez-Martinez, D., De Mees, C., Douhard, Q., Szpirer, C., and Bakker, J. (2008). Absence of gonadotropinreleasing hormone 1 and Kissl activation in alpha-fetoprotein knockout mice: prenatal estrogens defeminize the potential to show preovulatory luteinizing hormone surges. Endocrinology 149, 2333-2340.

Goodman, R. L., Lehman, M. N., Smith, J. T., Coolen, L. M., De Oliveira, C. V., Jafarzadehshirazi, M. R., Pereira, A., Iqbal, J., Caraty, A., Ciofi, P., and Clarke, I. J. (2007). Kisspeptin neurons in the arcuate nucleus of the ewe express both dynorphin A and neurokinin B. Endocrinology 148, 5752-5760.
Gore, A. C., Wu, T. J., Rosenberg, J. J., and Roberts, J. L. (1996). Gonadotropin-releasing hormone and NMDA receptor gene expression and colocalization change during puberty in female rats. J. Neurosci. 16, 5281-5289.

Gottsch, M. L., Clifton, D. K., and Steiner, R. A. (2006). Kisspeptin-GPR54 signaling in the neuroendocrine reproductive axis. Mol. Cell. Endocrinol. 254-255, 91-96.

Gottsch, M. L., Cunningham, M. J., Smith, J. T., Popa, S. M., Acohido, B. V., Crowley, W. F., Seminara, S., Clifton, D. K., and Steiner, R. A. (2004). A role for kisspeptins in the regulation of gonadotropin secretion in the mouse. Endocrinology 145, 4073-4077.

Gottsch, M. L., Navarro, V. M., Zhao, Z., Glidewell-Kenney, C., Weiss, J., Jameson, J. L., Clifton, D. K., Levine, J. E., and Steiner, R. A. (2009). Regulation of Kiss 1 and dynorphin gene expression in the murine brain by classical and nonclassical estrogen receptor pathways. J. Neurosci. 29, 9390-9395.

Gottsch, M. L., Popa, S. M., Lawhorn, J. K., Qiu, J., Tonsfeldt, K. J., Bosch, M. A., Kelly, M. J., Ronnekleiv, O. K., Sanz, E., McKnight, G. S., Clifton, D. K., Palmiter, R. D., and Steiner, R. A. (2011). Molecular properties of Kiss 1 neurons in the arcuate nucleus of the mouse. Endocrinology 152, 4298-4309.

Graber, J. A., Seeley, J. R., Brooks-Gunn, J., and Lewinsohn, P. M. (2004). Is pubertal timing associated with psychopathology in young adulthood. J. Am. Acad. Child Adolesc. Psychiatry 43, 718-726.

Hagenauer, M. H., King, A. F., Possidente, B., Mcginnis, M. Y., Lumia, A. R., Peckham, E. M., and Lee, T. M. (2011). Changes in circadian rhythms during puberty in Rattus norvegicus: developmental time course and gonadal dependency. Horm. Behav. 60, 46-57.

Han, S. K., Gottsch, M. L., Lee, K. J., Popa, S. M., Smith, J. T., Jakawich, S. K., Clifton, D. K., Steiner, R. A., and Herbison, A. E. (2005). Activation of gonadotropin-releasing hormone neurons by kisspeptin as a neuroendocrine switch for the onset of puberty. J. Neurosci. 25, 11349-11356.

Harris, G. C., and Levine, J. E. (2003). Pubertal acceleration of pulsatile gonadotropin-releasing hormone release in male rats as revealed by microdialysis. Endocrinology 144, 163-171.
Hazlerigg, D. G., and Wagner, G. C. (2006). Seasonal photoperiodism in vertebrates: from coincidence to amplitude. Trends Endocrinol. Metab. 17, 83-91.

He, P. J., Hirata, M., Yamauchi, N., Hashimoto, S., and Hattori, M. A. (2007). Gonadotropic regulation of circadian clockwork in rat granulosa cells. Mol. Cell. Biochem. 302, 111-118.

Herbison, A. E. (2008). Estrogen positive feedback to gonadotropinreleasing hormone $(\mathrm{GnRH})$ neurons in the rodent: the case for the rostral periventricular area of the third ventricle (RP3V). Brain Res. Rev. 57, 277-287.

Herbison, A. E., Porteous, R., Pape, J. R., Mora, J. M., and Hurst, P. R. (2008). Gonadotropin-releasing hormone neuron requirements for puberty, ovulation, and fertility. Endocrinology 149, 597-604.

Hickok, J. R., and Tischkau, S. A. (2009). In vivo circadian rhythms in gonadotropin-releasing hormone neurons. Neuroendocrinology 91, 110-120.

Hoffman, G. E., Le, W. W., Franceschini, I., Caraty, A., and Advis, J. P. (2011). Expression of fos and in vivo median eminence release of LHRH identifies an active role for preoptic area kisspeptin neurons in synchronized surges of LH and LHRH in the ewe. Endocrinology 152, 214-222.

Homma, T., Sakakibara, M., Yamada, S., Kinoshita, M., Iwata, K., Tomikawa, J., Kanazawa, T., Matsui, H., Takatsu, Y., Ohtaki, T., Matsumoto, H. Uenoyama, Y., Maeda, K., and Tsukamura, H. (2009). Significance of neonatal testicular sex steroids to defeminize anteroventral periventricular kisspeptin neurons and the $\mathrm{GnRH} / \mathrm{LH}$ surge system in male rats. Biol. Reprod. 81, 1216-1225.

Ibanez, L., De Zegher, F., and Potau, N. (1998a). Premature pubarche, ovarian hyperandrogenism, hyperinsulinism and the polycystic ovary syndrome: from a complex constellation to a simple sequence of prenatal onset. J. Endocrinol. Invest. 21 , 558-566.

Ibanez, L., Potau, N., Francois, I., and De Zegher, F. (1998b). Precocious pubarche, hyperinsulinism, and ovarian hyperandrogenism in girls: relation to reduced fetal growth. J. Clin Endocrinol. Metab. 83, 3558-3562.

Ibanez, L., Diaz, R., Lopez-Bermejo, A. and Marcos, M. V. (2009). Clinical spectrum of premature pubarche: links to metabolic syndrome and ovarian hyperandrogenism. Rev. Endocr. Metab. Disord. 10, 63-76.
Ibanez, L., Jimenez, R., and De Zegher, F. (2006). Early puberty-menarche after precocious pubarche: relation to prenatal growth. Pediatrics 117 117-121.

Ibanez, L., Potau, N., Zampolli, M., Prat, N., Virdis, R., Vicens-Calvet, E., and Carrascosa, A. (1996). Hyperinsulinemia in postpubertal girls with a history of premature pubarche and functional ovarian hyperandrogenism. J. Clin. Endocrinol. Metab. 81, 1237-1243.

Ibanez, L., Valls, C., Potau, N., Marcos, M. V., and De Zegher, F. (2001). Polycystic ovary syndrome after precocious pubarche: ontogeny of the lowbirthweight effect. Clin. Endocrinol. (Oxf) 55, 667-672.

Irwig, M. S., Fraley, G. S., Smith, J. T., Acohido, B. V., Popa, S. M., Cunningham, M. J., Gottsch, M. L., Clifton, D. K., and Steiner, R. A. (2004). Kisspeptin activation of gonadotropin releasing hormone neurons and regulation of KiSS-1 mRNA in the male rat. Neuroendocrinology 80, 264-272.

Jacobsen, B. K., Heuch, I., and Kvale, G. (2007). Association of low age at menarche with increased all-cause mortality: a 37-year follow-up of 61,319 Norwegian women. Am. J. Epidemiol. 166, 1431-1437.

Johansson, T., and Ritzen, E. M. (2005). Very long-term follow-up of girls with early and late menarche. Endocr. Dev. 8, 126-136.

Kaltiala-Heino, R., Kosunen, E., and Rimpela, M. (2003). Pubertal timing, sexual behaviour and selfreported depression in middle adolescence. J. Adolesc. 26, 531-545.

Kaplowitz, P. B., Slora, E. J., Wasserman, R. C., Pedlow, S. E., and Herman-Giddens, M. E. (2001). Earlier onset of puberty in girls: relation to increased body mass index and race. Pediatrics 108, 347-353.

Karman, B. N., and Tischkau, S. A (2006). Circadian clock gene expression in the ovary: effects of luteinizing hormone. Biol. Reprod. 75, 624-632.

Kasa-Vubu, J. Z., Barkan, A., Olton, P., Meckmongkol, T., Carlson, N. E., and Foster, C. M. (2002). Incomplete modified fast in obese early pubertal girls leads to an increase in 24-hour growth hormone concentration and a lessening of the circadian pattern in leptin. J. Clin. Endocrinol. Metab. 87, 1885-1893.

Kauffman, A. S. (2010a). Coming of age in the kisspeptin era: sex differences, development, and puberty. Mol. Cell. Endocrinol. 324, 51-63. 
Kauffman, A. S. (2010b). Gonadal and nongonadal regulation of sex differences in hypothalamic Kiss1 neurones. J. Neuroendocrinol. 22, 682-691.

Kauffman, A. S., Gottsch, M. L., Roa, J., Byquist, A. C., Crown, A., Clifton, D. K., Hoffman, G. E., Steiner, R. A., and Tena-Sempere, M. (2007). Sexual differentiation of Kiss 1 gene expression in the brain of the rat. Endocrinology 148, 1774-1783.

Kennaway, D. J., Boden, M. J., and Voultsios, A. (2004). Reproductive performance in female Clock Delta19 mutant mice. Reprod. Fertil. Dev. 16, 801-810.

Kennedy, G. C. (1969). Interactions between feeding behavior and hormones during growth. Ann. N. Y. Acad. Sci. 157, 1049-1061.

Khan, A. R., and Kauffman, A. S. (2011). The role of kisspeptin and RFRP-3 neurons in the circadiantimed preovulatory luteinizing hormone surge. J Neuroendocrinol. 24, 131-143.

Kile, J. P., Alexander, B. M., Moss, G. E., Hallford, D. M., and Nett, T. M. (1991). Gonadotropin-releasing hormone overrides the negative effect of reduced dietary energy on gonadotropin synthesis and secretion in ewes. Endocrinology 128, 843-849.

Kimura, F., Okano, H., and Kawakami, M. (1981). Development of circadian rhythms in serum hormone levels in the immature female rat. Neuroendocrinology 32, 19-23.

Kinsey-Jones, J. S., Li, X. F., Knox, A. M., Lin, Y. S., Milligan, S. R., Lightman, S. L., and O'Byrne, K. T. (2010). Corticotrophin-releasing factor alters the timing of puberty in the female rat. J. Neuroendocrinol. 22, 102-109.

Knox, A. M., Li, X. F., Kinsey-Jones, J. S., Wilkinson, E. S., Wu, X. Q., Cheng, Y. S., Milligan, S. R., Lightman, S. L., and O'Byrne, K. T. (2009). Neonatal lipopolysaccharide exposure delays puberty and alters hypothalamic Kiss1 and Kiss1r mRNA expression in the female rat. J. Neuroendocrinol. 21, 683-689.

Ko, C. H., and Takahashi, J. S. (2006). Molecular components of the mammalian circadian clock. Hum. Mol. Genet. 15(Suppl. 2), R271-R277.

Kotani, M., Detheux, M., Vandenbogaerde, A., Communi, D., Vanderwinden, J. M., Le Poul, E., Brezillon, S., Tyldesley, R., SuarezHuerta, N., Vandeput, F., Blanpain, C., Schiffmann, S. N., Vassart, G., and Parmentier, M. (2001). The metastasis suppressor gene KiSS1 encodes kisspeptins, the natural ligands of the orphan $G$ proteincoupled receptor GPR54. J. Biol. Chem. 276, 34631-34636.

Kowalska, E., Moriggi, E., Bauer, C., Dibner, C., and Brown, S. A. (2010). The circadian clock starts ticking at a developmentally early stage. J. Biol. Rhythms 25, 442-449.

Kudo, T., Akiyama, M., Kuriyama, K. Sudo, M., Moriya, T., and Shibata, S. (2004). Night-time restricted feeding normalises clock genes and Pai-1 gene expression in the $\mathrm{db} / \mathrm{db}$ mouse liver. Diabetologia 47, 1425-1436.

Lacey, J. V. Jr., Kreimer, A. R., Buys, S. S., Marcus, P. M., Chang, S. C., Leitzmann, M. F., Hoover, R. N., Prorok, P. C., Berg, C. D., and Hartge, P. (2009). Breast cancer epidemiology according to recognized breast cancer risk factors in the Prostate, Lung, Colorectal and Ovarian (PLCO) Cancer Screening Trial Cohort. BMC Cancer 9, 84. doi:10.1186/1471-2407-9-84

Lakshman, R., Forouhi, N., Luben, R., Bingham, S., Khaw, K., Wareham, N., and Ong, K. K. (2008). Association between age at menarche and risk of diabetes in adults: results from the EPIC-Norfolk cohort study. Diabetologia 51, 781-786.

Lamia, K. A., Sachdeva, U. M., Ditacchio, L., Williams, E. C., Alvarez, J. G., Egan, D. F., Vasquez, D. S., Juguilon, H., Panda, S., Shaw, R. J., Thompson, C. B., and Evans, R. M. (2009). AMPK regulates the circadian clock by cryptochrome phosphorylation and degradation. Science 326, 437-440.

Lapatto, R., Pallais, J. C., Zhang, D., Chan, Y. M., Mahan, A., Cerrato, F., Le, W. W., Hoffman, G. E., and Seminara, S. B. (2007). Kiss1-/mice exhibit more variable hypogonadism than Gpr54-/- mice. Endocrinology 148, 4927-4936.

Lee, D. K., Nguyen, T., O’Neill, G. P., Cheng, R., Liu, Y., Howard, A. D., Coulombe, N., Tan, C. P., TangNguyen, A. T., George, S. R., and O’Dowd, B. F. (1999). Discovery of a receptor related to the galanin receptors. FEBS Lett. 446, 103-107.

Lee, J. H., Miele, M. E., Hicks, D. J., Phillips, K. K., Trent, J. M., Weissman, B. E., and Welch, D. R. (1996). KiSS-1, a novel human malignant melanoma metastasissuppressor gene. J. Natl. Cancer Inst. 88, 1731-1737.

Lee, J. M., Appugliese, D., Kaciroti, N., Corwyn, R. F., Bradley, R. H., and Lumeng, J. C. (2007). Weight status in young girls and the onset of puberty. Pediatrics 119, e624-e630.
Lee, T. M., Hummer, D. L., Jechura, T. J., and Mahoney, M. M. (2004). Pubertal development of sex differences in circadian function: an animal model. Ann. N. Y. Acad. Sci. 1021, 262-275.

Levine, J. E., and Ramirez, V. D. (1982). Luteinizing hormone-releasing hormone release during the rat estrous cycle and after ovariectomy, as estimated with push-pull cannulae. Endocrinology 111, 1439-1448.

Lincoln, G., Messager, S., Andersson, H. and Hazlerigg, D. (2002). Temporal expression of seven clock genes in the suprachiasmatic nucleus and the pars tuberalis of the sheep: evidence for an internal coincidence timer. Proc. Natl. Acad. Sci. U.S.A. 99 , 13890-13895.

Liu, X., Lee, K., and Herbison, A. E. (2008). Kisspeptin excites gonadotropin-releasing hormone neurons through a phospholipase $\mathrm{C} /$ calcium-dependent pathway regulating multiple ion channels. Endocrinology 149, 4605-4614.

Louis, G. W., Greenwald-Yarnell, M. Phillips, R., Coolen, L. M., Lehman, M. N., and Myers, M. G. Jr. (2011). Molecular mapping of the neural pathways linking leptin to the neuroendocrine reproductive axis. Endocrinology 152, 2302-2310.

Luquet, S., Perez, F. A., Hnasko, T. S., and Palmiter, R. D. (2005). NPY/AgRP neurons are essential for feeding in adult mice but can be ablated in neonates. Science 310, 683-685.

Ma, Y. J., and Ojeda, S. R. (1997). Neuroendocrine control of female puberty: glial and neuronal interactions. J. Investig. Dermatol. Symp. Proc. 2, 19-22.

Matsui, H., Takatsu, Y., Kumano, S., Matsumoto, H., and Ohtaki, T. (2004). Peripheral administration of metastin induces marked gonadotropin release and ovulation in the rat. Biochem. Biophys. Res. Commun. 320, 383-388.

Mayer, C., Acosta-Martinez, M., Dubois, S. L., Wolfe, A., Radovick, S., Boehm, U., and Levine, J. E. (2010). Timing and completion of puberty in female mice depend on estrogen receptor alpha-signaling in kisspeptin neurons. Proc. Natl. Acad. Sci. U.S.A. 107, 22693-22698.

Mayer, C., and Boehm, U. (2011). Female reproductive maturation in the absence of kisspeptin/GPR54 signaling. Nat. Neurosci. 14, 704-710.

McCartney, C. R. (2010). Maturation of sleep-wake gonadotrophinreleasing hormone secretion across puberty in girls: potential mechanisms and relevance to the pathogenesis of polycystic ovary syndrome. J. Neuroendocrinol. 22, 701-709.

McCartney, C. R., Blank, S. K., Prendergast, K. A., Chhabra, S., Eagleson, C. A., Helm, K. D., Yoo, R., Chang, R. J., Foster, C. M., Caprio, S., and Marshall, J. C. (2007). Obesity and sex steroid changes across puberty: evidence for marked hyperandrogenemia in pre- and early pubertal obese girls. J. Clin. Endocrinol. Metab. 92, 430-436.

Messager, S., Chatzidaki, E. E., Ma, D. Hendrick, A. G., Zahn, D., Dixon, J. Thresher, R. R., Malinge, I., Lomet, D., Carlton, M. B., Colledge, W. H., Caraty, A., and Aparicio, S. A. (2005). Kisspeptin directly stimulates gonadotropin-releasing hormone release via $\mathrm{G}$ protein-coupled receptor 54. Proc. Natl. Acad. Sci. U.S.A. 102, 1761-1766.

Michaud, P. A., Suris, J. C., and Deppen, A. (2006). Gender-related psychological and behavioural correlates of pubertal timing in a national sample of Swiss adolescents. Mol. Cell. Endocrinol. 254-255, 172-178.

Miller, B. H., Olson, S. L., Turek, F. W., Levine, J. E., Horton, T. H., and Takahashi, J. S. (2004). Circadian clock mutation disrupts estrous cyclicity and maintenance of pregnancy. Curr. Biol. 14, 1367-1373.

Moenter, S. M., Brand, R. M., Midgley, A. R., and Karsch, F. J. (1992). Dynamics of gonadotropinreleasing hormone release during a pulse. Endocrinology 130, 503-510.

Moenter, S. M., and DeFazio, R. A. (2005). Endogenous gammaaminobutyric acid can excite gonadotropin-releasing hormone neurons. Endocrinology 146, 5374-5379.

Moguilevsky, J. A., and Wuttke, W. (2001). Changes in the control of gonadotrophin secretion by neurotransmitters during sexual development in rats. Exp. Clin. Endocrinol. Diabetes 109, 188-195.

Moorman, P. G., Palmieri, R. T., Akushevich, L., Berchuck, A., and Schildkraut, J. M. (2009). Ovarian cancer risk factors in African-American and white women. Am. J. Epidemiol. 170, 598-606.

Mor, V., and Unnikrishnan, M. K. (2011). 5'-Adenosine monophosphate-activated protein kinase and the metabolic syndrome. Endocr. Metab. Immune Disord. Drug Targets 11, 206-216.

Morin, L. P., and Cummings, L. A. (1981). Effect of surgical or photoperiodic castration, testosterone 
replacement or pinealectomy on male hamster running rhythmicity. Physiol. Behav. 26, 825-838.

Mosko, S. S., and Moore, R. Y. (1979). Neonatal ablation of the suprachiasmatic nucleus. Effects on the development of the pituitary-gonadal axis in the female rat. Neuroendocrinology 29, 350-361.

Mounzih, K., Lu, R., and Chehab, F. F. (1997). Leptin treatment rescues the sterility of genetically obese ob/ob males. Endocrinology 138, 1190-1193.

Muir, A. I., Chamberlain, L., Elshourbagy, N. A., Michalovich, D., Moore, D. J., Calamari, A., Szekeres, P. G., Sarau, H. M., Chambers, J. K., Murdock, P., Steplewski, K., Shabon, U., Miller, J. E., Middleton, S. E., Darker, J. G., Larminie, C. G., Wilson, S., Bergsma, D. J., Emson, P., Faull, R., Philpott, K. L., and Harrison, D. C. (2001). AXOR12, a novel human $\mathrm{G}$ protein-coupled receptor, activated by the peptide KiSS-1. J. Biol. Chem. 276, 28969-28975.

Musso, C., Cochran, E., Javor, E., Young, J., Depaoli, A. M., and Gorden, P. (2005). The long-term effect of recombinant methionyl human leptin therapy on hyperandrogenism and menstrual function in female and pituitary function in male and female hypoleptinemic lipodystrophic patients. Metab. Clin. Exp. 54, 255-263.

Must, A., Naumova, E. N., Phillips, S. M., Blum, M., Dawson-Hughes, B., and Rand, W. M. (2005). Childhood overweight and maturational timing in the development of adult overweight and fatness: the Newton Girls Study and its follow-up. Pediatrics 116, 620-627.

Nakao, N., Yasuo, S., Nishimura, A., Yamamura, T., Watanabe, T., Anraku, T., Okano, T., Fukada, Y., Sharp, P. J., Ebihara, S., and Yoshimura, T. (2007). Circadian clock gene regulation of steroidogenic acute regulatory protein gene expression in preovulatory ovarian follicles. Endocrinology 148, 3031-3038.

Navarro, V. M., Fernandez-Fernandez, R., Castellano, J. M., Roa, J., Mayen, A., Barreiro, M. L., Gaytan, F., Aguilar, E., Pinilla, L., Dieguez, C., and Tena-Sempere, M. (2004). Advanced vaginal opening and precocious activation of the reproductive axis by KiSS-1 peptide, the endogenous ligand of GPR54. J. Physiol. 561, 379-386.

Norjavaara, E., Ankarberg, C., and Albertsson-Wikland, K. (1996). Diurnal rhythm of 17 beta-estradiol secretion throughout pubertal development in healthy girls: evaluation by a sensitive radioimmunoassay. J. Clin. Endocrinol. Metab. 81, 4095-4102.

Odell, W. D., and Swerdloff, R. S. (1976). Etiologies of sexual maturation: a model system based on the sexually maturing rat. Recent Prog. Horm. Res. 32, 245-288.

Odell, W. D., Swerdloff, R. S., Bain, J., Wollesen, F., and Grover, P. K. (1974). The effect of sexual maturation on testicular response to $\mathrm{LH}$ stimulation of testosterone secretion in the intact rat. Endocrinology 95, 1380-1384.

Oerter, K. E., Uriarte, M. M., Rose, S. R., Barnes, K. M., and Cutler, G. B. Jr. (1990). Gonadotropin secretory dynamics during puberty in normal girls and boys. J. Clin. Endocrinol. Metab. 71, 1251-1258.

Ogden, C. L., Carroll, M. D., Curtin, L. R., Mcdowell, M. A., Tabak, C. J., and Flegal, K. M. (2006). Prevalence of overweight and obesity in the United States, 1999-2004. JAMA 295, 1549-1555

Ohtaki, T., Shintani, Y., Honda, S., Matsumoto, H., Hori, A., Kanehashi, K., Terao, Y., Kumano, S., Takatsu, Y., Masuda, Y., Ishibashi, Y., Watanabe, T., Asada, M., Yamada, T., Suenaga, M., Kitada, C., Usuki, S., Kurokawa, T., Onda, H., Nishimura, O., and Fujino, M. (2001). Metastasis suppressor gene KiSS-1 encodes peptide ligand of a G-protein-coupled receptor. Nature 411, 613-617.

Ojeda, S. R., and Ma, Y. J. (1999). Glial-neuronal interactions in the neuroendocrine control of mammalian puberty: facilitatory effects of gonadal steroids. J. Neurobiol. 40, 528-540.

Ojeda, S. R., Ma, Y. J., Lee, B. J., and Prevot, V. (2000). Glia-to-neuron signaling and the neuroendocrine control of female puberty. Recent Prog. Horm. Res. 55, 197-223; discussion 223-194.

Ojeda, S. R., Urbanski, H. F., Katz, K. H., and Costa, M. E. (1986). Activation of estradiol-positive feedback at puberty: estradiol sensitizes the LHRH-releasing system at two different biochemical steps. Neuroendocrinology 43, 259-265.

Ojeda, S. R., Wheaton, J. E., Jameson, H. E., and Mccann, S. M. (1976). The onset of puberty in the female rat: changes in plasma prolactin, gonadotropins, luteinizing hormone-releasing hormone (LHRH), and hypothalamic LHRH content. Endocrinology 98, 630-638. Olcese, J., Domagalski, R., Bednorz, A., Weaver, D. R., Urbanski, H.
F., Reuss, S., and Middendorff, R. (2003). Expression and regulation of mPerl in immortalized GnRH neurons. Neuroreport 14, 613-618.

Ong, K. K., Emmett, P., Northstone, K., Golding, J., Rogers, I., Ness, A. R. Wells, J. C., and Dunger, D. B. (2009). Infancy weight gain predicts childhood body fat and age at menarche in girls. J. Clin. Endocrinol. Metab. 94, 1527-1532.

Orozco-Solis, R., Matos, R. J., Lopes De Souza, S., Grit, I., Kaeffer, B., Manhaes De Castro, R., and BolanosJimenez, F. (2011). Perinatal nutrient restriction induces long-lasting alterations in the circadian expression pattern of genes regulating food intake and energy metabolism. Int. J. Obes. (Lond.) 35, 990-1000.

Ostovich, J. M., and Sabini, J. (2005). Timing of puberty and sexuality in men and women. Arch. Sex. Behav. 34, 197-206.

Ozata, M., Ozdemir, I. C., and Licinio, J. (1999). Human leptin deficiency caused by a missense mutation: multiple endocrine defects, decreased sympathetic tone, and immune system dysfunction indicate new targets for leptin action, greater central than peripheral resistance to the effects of leptin, and spontaneous correction of leptin-mediated defects. J. Clin. Endocrinol. Metab. 84, 3686-3695.

Palmert, M. R., Radovick, S., and Boepple, P. A. (1998). The impact of reversible gonadal sex steroid suppression on serum leptin concentrations in children with central precocious puberty. J. Clin. Endocrinol. Metab. 83, 1091-1096.

Petridou, E., Syrigou, E., Toupadaki, N., Zavitsanos, X., Willett, W., and Trichopoulos, D. (1996). Determinants of age at menarche as early life predictors of breast cancer risk. Int. J. Cancer 68, 193-198.

Pineda, R., Garcia-Galiano, D., Roseweir, A., Romero, M., SanchezGarrido, M. A., Ruiz-Pino, F. Morgan, K., Pinilla, L., Millar, R. P., and Tena-Sempere, M. (2009). Critical roles of kisspeptins in female puberty and preovulatory gonadotropin surges as revealed by a novel antagonist. Endocrinology $151,722-730$.

Plant, T. M. (1985). A study of the role of the postnatal testes in determining the ontogeny of gonadotropin secretion in the male rhesus monkey (Macaca mulatta). Endocrinology 116, 1341-1350.

Plant, T. M. (1986). A striking sex difference in the gonadotropin response to gonadectomy during infantile development in the rhesus monkey (Macaca mulatta). Endocrinology 119, 539-545.

Plant, T. M. (2006). The role of KiSS1 in the regulation of puberty in higher primates. Eur. J. Endocrinol. 155(Suppl. 1), S11-S16.

Popa, S. M., Clifton, D. K., and Steiner, R. A. (2008). The role of kisspeptins and GPR54 in the neuroendocrine regulation of reproduction. Annu. Rev. Physiol. 70, 213-238.

Porcu, E., Venturoli, S., Longhi, M., Fabbri, R., Paradisi, R., and Flamigni, C. (1997). Chronobiologic evolution of luteinizing hormone secretion in adolescence: developmental patterns and speculations on the onset of the polycystic ovary syndrome. Fertil. Steril. 67, 842-848.

Porteous, R., Petersen, S. L., Yeo, S. H., Bhattarai, J. P., Ciofi, P., De Tassigny, X. D., Colledge, W. H., Caraty, A., and Herbison, A. E. (2011). Kisspeptin neurons co-express metenkephalin and galanin in the rostral periventricular region of the female mouse hypothalamus. J. Comp. Neurol. 519, 3456-3469.

Prevot, V., Lomniczi, A., Corfas, G., and Ojeda, S. R. (2005). erbB1 and erbB-4 receptors act in concert to facilitate female sexual development and mature reproductive function. Endocrinology 146, 1465-1472.

Puig-Duran, E., and MacKinnon, P. C. (1978). A critical period for positive feedback in immature (21-day-old) rats. J. Endocrinol. 76, 311-320.

Quennell, J. H., Howell, C. S., Roa, J., Augustine, R. A., Grattan, D. R. and Anderson, G. M. (2011). Leptin deficiency and diet-induced obesity reduce hypothalamic kisspeptin expression in mice. Endocrinology 152, 1541-1550.

Quennell, J. H., Mulligan, A. C., Tups, A., Liu, X., Phipps, S. J., Kemp, C. J., Herbison, A. E., Grattan, D. R., and Anderson, G. M. (2009). Leptin indirectly regulates gonadotropinreleasing hormone neuronal function. Endocrinology 150, 2805-2812.

Rage, F., Hill, D. F., Sena-Esteves, M., Breakefield, X. O., Coffey, R. J., Costa, M. E., Mccann, S. M., and Ojeda, S. R. (1997). Targeting transforming growth factor alpha expression to discrete loci of the neuroendocrine brain induces female sexual precocity. Proc. Natl. Acad. Sci. U.S.A. 94, 2735-2740.

Reardon, L. E., Leen-Feldner, E. W., and Hayward, C. (2009). A critical review of the empirical literature on the relation between anxiety and puberty. Clin. Psychol. Rev. 29, 1-23. 
Reid, R. L., and Van Vugt, D. A. (1987). Weight-related changes in reproduction function. Fertil. Steril. 48, 905-913.

Reppert, S. M., and Weaver, D. R. (2002). Coordination of circadian timing in mammals. Nature 418, 935-941.

Resuehr, D., Wildemann, U., Sikes, H., and Olcese, J. (2007). E-box regulation of gonadotropin-releasing hormone $(\mathrm{GnRH})$ receptor expression in immortalized gonadotrope cells. Mol. Cell. Endocrinol. 278, 36-43.

Riman, T., Nilsson, S., and Persson, I. R. (2004). Review of epidemiological evidence for reproductive and hormonal factors in relation to the risk of epithelial ovarian malignancies. Acta Obstet. Gynecol. Scand. 83, 783-795.

Rittmaster, R. S., Deshwal, N., and Lehman, L. (1993). The role of adrenal hyperandrogenism, insulin resistance, and obesity in the pathogenesis of polycystic ovarian syndrome. J. Clin. Endocrinol. Metab. 76, 1295-1300.

Roa, J., Vigo, E., Garcia-Galiano, D., Castellano, J. M., Navarro, V. M., Pineda, R., Dieguez, C., Aguilar, E., Pinilla, L., and TenaSempere, M. (2008). Desensitization of gonadotropin responses to kisspeptin in the female rat: analyses of LH and FSH secretion at different developmental and metabolic states. Am. J. Physiol. Endocrinol. Metab. 294, E1088-E1096.

Roland, A. V., and Moenter, S. M. (2011). Prenatal androgenization of female mice programs an increase in firing activity of gonadotropinreleasing hormone (GnRH) neurons that is reversed by metformin treatment in adulthood. Endocrinology 152, 618-628.

Rosenfield, R. L., Lipton, R. B., and Drum, M. L. (2009). Thelarche, pubarche, and menarche attainment in children with normal and elevated body mass index. Pediatrics 123, 84-88.

Scheer, F. A., Chan, J. L., Fargnoli, J., Chamberland, J., Arampatzi, K., Shea, S. A., Blackburn, G. L., and Mantzoros, C. S. (2010). Day/night variations of high-molecular-weight adiponectin and lipocalin-2 in healthy men studied under fed and fasted conditions. Diabetologia 53, 2401-2405.

Schneider, J. E., Blum, R. M., and Wade, G. N. (2000). Metabolic control of food intake and estrous cycles in Syrian hamsters. I. Plasma insulin and leptin. Am. J. Physiol. Regul. Integr. Comp. Physiol. 278, R476-R485.
Schneider, J. E., Friedenson, D. G., Hall, A. J., and Wade, G. N. (1993). Glucoprivation induces anestrus and lipoprivation may induce hibernation in Syrian hamsters. Am. J. Physiol. 264, R573-R577.

Schwartz, M. W., Woods, S. C., Porte, D. Jr., Seeley, R. J., and Baskin, D. G. (2000). Central nervous system control of food intake. Nature 404, 661-671.

Sellix, M. T., and Menaker, M. (2010). Circadian clocks in the ovary. Trends Endocrinol. Metab. 21, 628-636.

Seminara, S. B., Messager, S., Chatzidaki, E. E., Thresher, R. R., Acierno, J. S. Jr., Shagoury, J. K., Bo-Abbas, Y., Kuohung, W., Schwinof, K. M., Hendrick, A. G., Zahn, D., Dixon, J., Kaiser, U. B., Slaugenhaupt, S. A., Gusella, J. F., O'Rahilly, S., Carlton, M. B., Crowley, W. F. Jr., Aparicio, S. A., and Colledge, W. H. (2003). The GPR54 gene as a regulator of puberty. N. Engl. J. Med. 349, 1614-1627.

Sethi, S., and Chaturvedi, C. M. (2011). Temporal phase relation of circadian neural oscillations as the basis of testicular maturation in mice: a test of a coincidence model. J. Biosci. 35, 571-581.

Shea, S. A., Hilton, M. F., Orlova, C., Ayers, R. T., and Mantzoros, C. S. (2005). Independent circadian and sleep/wake regulation of adipokines and glucose in humans. J. Clin. Endocrinol. Metab. 90, 2537-2544.

Siegel, J. M., Yancey, A. K., Aneshensel, C. S., and Schuler, R. (1999). Body image, perceived pubertal timing, and adolescent mental health. $J$. Adolesc. Health 25, 155-165.

Sim, J. A., Skynner, M. J., and Herbison, A. E. (2001). Heterogeneity in the basic membrane properties of postnatal gonadotropin-releasing hormone neurons in the mouse. $J$. Neurosci. 21, 1067-1075.

Sinha, M. K., Ohannesian, J. P., Heiman, M. L., Kriauciunas, A., Stephens, T. W., Magosin, S., Marco, C., and Caro, J. F. (1996). Nocturnal rise of leptin in lean, obese, and non-insulindependent diabetes mellitus subjects. J. Clin. Invest. 97, 1344-1347.

Sirinathsinghji, D. J., Motta, M., and Martini, L. (1985). Induction of precocious puberty in the female rat after chronic naloxone administration during the neonatal period: the opiate 'brake' on prepubertal gonadotrophin secretion. J. Endocrinol. 104, 299-307.

Sisk, C. L., Richardson, H. N., Chappell, P. E., and Levine, J. E. (2001). In vivo gonadotropin-releasing hormone secretion in female rats during peripubertal development and on proestrus. Endocrinology 142, 2929-2936.

Smith, J. T., Acohido, B. V., Clifton, D. K., and Steiner, R. A. (2006a). KiSS-1 neurones are direct targets for leptin in the ob/ob mouse. $J$. Neuroendocrinol. 18, 298-303.

Smith, J. T., Popa, S. M., Clifton, D. K. Hoffman, G. E., and Steiner, R. A. (2006b). Kiss1 neurons in the forebrain as central processors for generating the preovulatory luteinizing hormone surge. J. Neurosci. 26, 6687-6694.

Smith, J. T., Clay, C. M., Caraty, A., and Clarke, I. J. (2007). KiSS-1 messenger ribonucleic acid expression in the hypothalamus of the ewe is regulated by sex steroids and season. Endocrinology 148, 1150-1157.

Smith, J. T., Cunningham, M. J., Rissman, E. F., Clifton, D. K., and Steiner, R. A. (2005). Regulation of Kiss 1 gene expression in the brain of the female mouse. Endocrinology 146, 3686-3692.

Son, G. H., Chung, S., Choe, H. K., Kim, H. D., Baik, S. M., Lee, H., Lee, H. W., Choi, S., Sun, W., Kim, H., Cho, S., Lee, K. H., and Kim, K. (2008). Adrenal peripheral clock controls the autonomous circadian rhythm of glucocorticoid by causing rhythmic steroid production. Proc. Natl. Acad. Sci. U.S.A. 105, 20970-20975.

Sorensen, K., Aksglaede, L., Petersen, J. H., and Juul, A. (2010). Recent changes in pubertal timing in healthy Danish boys: associations with body mass index. J. Clin. Endocrinol. Metab. 95, 263-270.

Stice, E., Presnell, K., and Bearman, S. K. (2001). Relation of early menarche to depression, eating disorders, substance abuse, and comorbid psychopathology among adolescent girls. Dev. Psychol. 37, 608-619.

Suter, K. J., Pohl, C. R., and Wilson, M. E. (2000). Circulating concentrations of nocturnal leptin, growth hormone, and insulin-like growth factor-I increase before the onset of puberty in agonadal male monkeys: potential signals for the initiation of puberty. J. Clin. Endocrinol. Metab. 85, 808-814.

Swerdloff, R. S., Batt, R. A., and Bray, G. A. (1976). Reproductive hormonal function in the genetically obese (ob/ob) mouse. Endocrinology 98, 1359-1364.

Tarry-Adkins, J. L., Chen, J. H., Smith, N. S., Jones, R. H., Cherif, H., and Ozanne, S. E. (2009). Poor maternal nutrition followed by accelerated postnatal growth leads to telomere shortening and increased markers of cell senescence in rat islets. FASEB J. 23, 1521-1528.

Tartaglia, L. A., Dembski, M., Weng, X., Deng, N., Culpepper, J., Devos, R., Richards, G. J., Campfield, L. A., Clark, F. T., Deeds, J., Muir, C., Sanker, S., Moriarty, A., Moore, K. J., Smutko, J. S., Mays, G. G., Wool, E. A., Monroe, C. A., and Tepper, R. I. (1995). Identification and expression cloning of a leptin receptor, OB-R. Cell 83, 1263-1271.

Tena-Sempere, M. (2008). Ghrelin as a pleotrophic modulator of gonadal function and reproduction. Nat. Clin. Pract. Endocrinol. Metab. 4, 666-674.

Titus-Ernstoff, L., Perez, K., Cramer, D. W., Harlow, B. L., Baron, J. A., and Greenberg, E. R. (2001). Menstrual and reproductive factors in relation to ovarian cancer risk. $\mathrm{Br}$. J. Cancer 84, 714-721.

Tonsfeldt, K. J., Goodall, C. P., Latham, K. L., and Chappell, P. E. (2011). Oestrogen induces rhythmic expression of the kisspeptin-1 receptor GPR54 in hypothalamic gonadotrophinreleasing hormone-secreting GT1-7 cells. J. Neuroendocrinol. 23, 823-830.

True, C., Kirigiti, M. A., Kievit, P., Grove, K. L., and Susan Smith, M. (2011). Leptin is not the critical signal for kisspeptin or luteinising hormone restoration during exit from negative energy balance. J Neuroendocrinol. 23, 1099-1112.

Um, J. H., Pendergast, J. S., Springer, D. A., Foretz, M., Viollet, B., Brown, A., Kim, M. K., Yamazaki, S., and Chung, J. H. (2011). AMPK regulates circadian rhythms in a tissueand isoform-specific manner. PLoS ONE 6, e18450. doi:10.1371/journal.pone.0018450

Urbanski, H. F., and Ojeda, S. R. (1987). Activation of luteinizing hormone-releasing hormone release advances the onset of female puberty. Neuroendocrinology 46, 273-276.

Urbanski, H. F., and Ojeda, S. R. (1990). A role for $N$-methyl-D-aspartate (NMDA) receptors in the control of LH secretion and initiation of female puberty. Endocrinology 126, 1774-1776.

van Jaarsveld, C. H., Fidler, J. A., Simon, A. E., and Wardle, J. (2007). Persistent impact of pubertal timing on trends in smoking, food choice, activity, and stress in adolescence. Psychosom. Med. 69, 798-806. 
Jolson and Chapel

Recent advances in pubertal progression

Vo, C., and Carney, M. E. (2007). Ovarian cancer hormonal and environmental risk effect. Obstet. Gynecol. Chin. North Am. 34, 687-700, viii.

Wade, G. N., and Schneider, J. E. (1992). Metabolic fuels and reproduction in female mammals. Neurosci. Biobehov. Rev. 16, 235-272.

Wade, G. N., Schneider, J. E., and Li, H. Y. (1996). Control of fertility by metabolic cues. Am. J. Physiol. 270, E1-E19.

Walvoord, E. C. (2010). The timing of puberty: is it changing? Does it matter? J. Adolesc. Health 47, 433-439.

Watanabe, G., and Terasawa, E. (1989). In vive release of luteinizing hormove releasing hormone increases with puberty in the female roesur monkey. Endocrinology 125, 92-99.

Welt, C. K., Chan, J. L., Bullen, J., Murthy, R., Smith, P., Depaoli, A. M., Karalis, A., and Mantzoros, C. S. (2004). Recombinant human eptin in women with hypothalamic amenorrhea. N. Encl. J. Med. 351, 987-997.

Wilson, M. E., Fisher, J., Chikazawa, K., Yoda, R., Legendre, A., Mook, D., and Gould, K. G. (2003). Leptin administration increases nocturnal concentrations of luteinizing hormove and growth hormone in juvenile female rhesus monkeys. J. Cline. Endocrinol. Metal. 88, 4874-4883.

Windsor-Engnell, B. M., Kasuya, E., Mizuno, M., Keen, K. L., and Terasawa, E. (2007). An increase in in vive release of LHRH and precocious puberty by posterior hypothalamic lesions in female rhesus monkeys (Maraca mulatto). Am. J. Physiol. Endocrinol. Metal. 292, E1000-E1009.

Wu, F. C., Butler, G. E., Kelnar, C. J., Stirling, H. F., and Huhtaniemi, I. (1991). Patterns of pulsatile luteinizing hormone and folliclestimulating hormone secretion in prepubertal (midchildhood) boys and girls and patients with idopathic hypogonadotropic hypogonudism (Kallmann's syndrome): a study using an ultrasensitive timeresolved immunofluorometric assay. J. Chin. Endocrinol. Metal. 72, 1229-1237.

Wyshak, G., and Frisch, R. E. (1982). Evidence for a secular trend in age of menarche. N. Encl. J. Med. 306, 1033-1035.
Yellon, S. M., and Foster, D. L. (1986). Melatonin rhythms time photoperiod-induced puberty in the female lamb. Endocrinology 119, 44-49.

Yoo, S. H., Yamazaki, S., Lowrey, P. L., Shimomura, K., Ko, C. H., Buhr, E. D., Siepka, S. M., Hong, H. K., Oh, W. J., Yoo, O. J., Menaker, M., and Takahashi, J. S. (2004). PERIOD2::LUCIFERASE real-time reporting of circadian dynamics reveals persistent circadian oscillatons in mouse peripheral tissues. Proc. Natl. Acid. Sci. U.S.A. 101, 5339-5346.

Yura, S., Ogawa, Y., Sagawa, N., Masuzaki, H., Itoh, H., Ebihara, K., Aizawa-Abe, M., Fiji, S., and Nakao, K. (2000). Accelerated puberty and late-onset hypothalamic hypogonadism in female transgenic skinny mice overexpressing leptin. J. Chin. Invest. 105, 749-755.

Lehr, J. L., Colbert, K. M., Sick, C. L., and Klump, K. L. (2007). An association of early puberty with disordered eating and anxiety in a population of undergraduate women and men. Hort. Behave. 52, 427-435.

Chang, Y., Proenca, R., Maffei, M., Barone, M., Leopold, L., and
Friedman, J. M. (1994). Positional cloning of the mouse obese gene and its human homologue. Nature 372, 425-432.

Conflict of Interest Statement: The authors declare that the research was conducted in the absence of any commercia or financial relationships that could be construed as a potential conflick of interest.

Received: 07 September 2011; accepted: 08 March 2012; published online: 28 March 2012.

Citation: Tolson KP and Chappell PE (2012) The changes they are a-timed: metabolism, endogenous clocks, and the timing of puberty. Front. Endocrine. 3:45. do: 10.3389/fendo.2012.00045 This article was submitted to Frontiers in Systems and Translational Endocrinolorgy, a specialty of Frontiers in Endocrinolorgy.

Copyright (c) 2012 Jolson and Chappelt. This is an open-access article distribute under the terms of the Cheative Commons Attribution Non Commercial License, which permits noncommercial use, distribution, and reprodiction in other forums, provided the original authors and source are credited.

www.frontiersin.org

March 2012 | Volume 3 | Article 45 | 17 